\title{
How does monetary policy respond to the dynamics of the shadow banking sector?*
}

\author{
Ricardo M. Sousa ${ }^{\$}$
}

\begin{abstract}
We investigate the response of the central bank to the change in size of non-bank financial intermediaries. Using quarterly data for the U.S. over the period 1946:Q1-2016Q4, we find that when faced with an increase in the asset growth of the securities' brokers and dealers and the shadow banking sector, the monetary authority reacts by raising the short-term nominal interest rate. This response is stronger in the case of sharp variation in the size of the balance sheet of nonbank financial intermediaries. From a policy perspective, our study suggests that an extended version of the original Taylor rule - embedding both price stability and financial stability concerns provides a good characterisation of the monetary policy reaction function.
\end{abstract}

JEL: Monetary policy, Taylor rule, shadow banking.

Keywords: E21, E43, E51, E53.

\footnotetext{
${ }^{*}$ We are grateful to participants to the $2^{\text {nd }}$ Society for Economic Measurement (SEM, Paris) Annual Conference, the $4^{\text {th }}$ International Symposium in Computational Economics and Finance (ISCEF, Paris), the $3^{\text {rd }}$ International Workshop on "Financial Markets and Nonlinear Dynamics" (FMND, Paris), the $16^{\text {th }}$ Annual Conference of the European Economics and Finance Society (EEFS) and the $49^{\text {th }}$ Money, Macro and Finance (MMF) Annual Conference, and to Joscha Beckmann, Georgios Chortareas, Gilles Dufrénot, Sushanta Mallick and Hyun Song Shin, for their constructive comments and suggestions that considerably improved this paper.

\# University of Palermo, Department of Economics, Business and Statistics (SEAS), Viale delle Scienze, 90128 Palermo, Italy. Email: luca.agnello01@unipa.it.

${ }^{ \pm}$Loughborough University, School of Business and Economics, Loughborough, Leicestershire LE11 3TU, United Kingdom; University of Minho, Economic Policies Research Unit (NIPE), Campus of Gualtar, 4710-057 - Braga, Portugal. Email: V.M.Q.Castro@lboro.ac.uk.

+ University of Evry, 2, rue Facteur Cheval, 91025 Evry, France. Email:fredj.jawadi@univ-evry.fr.

$\$$ University of Minho, Department of Economics and Economic Policies Research Unit (NIPE), Campus of Gualtar, 4710-057 - Braga, Portugal; London School of Economics and Political Science, LSE Alumni Association, Houghton Street, London WC2A 2AE, United Kingdom. E-mails: rjsousa@eeg.uminho.pt, rjsousa@alumni.lse.ac.uk. This paper is financed by National Funds of the FCT - Portuguese Foundation for Science and Technology within the project "UID/ECO/03182/2019".
} 


\section{Introduction}

Monetary policy making has substantially evolved over time. In its original framework, monetary policy could be thought as an institutional arrangement aimed at guaranteeing a standardised account unit to facilitate trade (Chadha, 2018). In the late 18th and 19th centuries, the occurrence of banking and financial crises led to the belief that a gold standard, low public debt and constrained policy rate changes were key to the stability of the monetary exchange rate.

However, the World Wars I and II and the (previous suspension and subsequent) downfall of the Gold Standard paved the way for the implementation of countercyclical fiscal and monetary policies. In this context, central banks were established to provide fiscal support to states emerging from military conflicts and inflation and growth became key indicators for the evaluation of government performance (Bordo, 2017). Not surprisingly, the post-war period was characterised by a significant amount of effort devoted to emphasising the importance of central bank independence, modelling the linkages between monetary policy and real economic activity, as well as to understanding the optimal policy response to fluctuations in the output gap and the inflation rate and the advantages of an inflation-targeting framework (White, 2001).

Against this backdrop, the original work of Taylor (1993) is formulated, postulating that the central bank sets the short-term interest rate based on information about current inflation and the business cycle. Several studies followed up, developing different versions of the monetary authority's reaction function, which included among others: (i) a lagged interest rate to capture interest rate smoothing or monetary policy inertia (Woodford, 1999); (ii) features of forwardlooking behaviour, as well as the role of inflation targeting (Clarida et al., 1998) or real-time data in the central bank's information set (Orphanides, 2001); and (iii) data uncertainty (Orphanides, 2003) or misspecifications due to correlation of shocks (Rudebusch, 2002).

Yet, the Great Moderation period and the subsequent Great Recession made it clear that financial risks can mount even if they do not initially materialise into business cycle risks. Similarly, they questioned the so called "benign neglect", that is, the idea that central banks can 
mainly focus on macroeconomic developments and generally ignore financial booms (Filardo and Rungcharoenkitkul, 2016). Indeed, the financial crisis of 2008-2009 has raised fundamental questions about the goals of monetary policy and the role that the central bank can have in weathering the various macroeconomic dynamics with which it is continuously confronted. ${ }^{1}$ For example, Taylor (2009) puts forward the argument that excessively expansionary monetary policy in the pre-crisis period helps to explain the emergence and the severity of the financial turmoil.

Thus, some authors highlighted the relevance of "leaning against the wind" monetary policies (Borio and Lowe, 2002; BIS, 2014, 2016), whereby the central bank sets a policy interest rate that is somewhat higher than what would be consistent with a "pure" or "flexible" inflation targeting regime in order to account for financial stability effects (Svensson, 2017). Consequently, the standard Taylor rule could incorporate the dynamics of equity prices (Chadha et al., 2004; Rigobon and Sack, 2004; Bernanke and Kuttner, 2005; Wongswan, 2009), ${ }^{2}$ housing prices (Aoki et al., 2004; Iacoviello, 2005; Iacoviello and Minetti, 2008; Bjornland et al., 2010; Iacoviello and Neri, 2010) or, more generally, asset wealth (Sousa, 2010). ${ }^{3}$ Castro and Sousa (2012) show that while asset wealth composition (not asset prices) drives the formulation of monetary policy, the central banks attempts to counteract undesirable financial wealth fluctuations can lead to disruptions in housing wealth. BIS (2015) notes that interest rate hikes may be needed even in the absence of inflation and continuing output gaps, and Field (2015) highlights that rising leverage and debt service-to-income ratios call for prompt policy measures. All in all, these extensions of the standard

\footnotetext{
${ }^{1}$ Some of the most visible facets of the world economy in the aftermath of the Lehman Brothers' collapse were the boom-bust housing market cycle roots (Agnello et al., 2015), the sharp rise in financial stress (Mallick and Sousa, 2013; Jawadi et al., 2018), the nexus between monetary and financial stability (Granville and Mallick, 2009; Sousa, 2010; Castro, 2011; Jawadi et al., 2017), the bank-sovereign linkages and their implications for capital markets' exclusion (Agnello et al., 2018a, 2018b), the lack of business cycle synchronization (Rafiq and Mallick, 2008; Mallick and Mohsin, 2016), the adoption of fiscal consolidation measurs (Chortareas, 2013; Agnello et al., 2013; Dufrénot et al., 2018), and a significant total factor productivity (TFP) slowdown (Jalles, 2015a, 2015b). The deleterious effects of the Great Recession are witnessed by abnormally large macroeconomic forecast errors (Jalles, 2015c, 2017a, 2017b), and casted doubts about financial intermediation undertaken by the banking sector when institutional quality is poor (Jalles, 2016).

${ }^{2}$ In contrast, Bernanke and Gertler (2001) consider that, once the predictive inflation dynamics content embedded in asset prices has been controlled for, central banks should avoid to react to these.

${ }^{3}$ Other studies have focused on a different question, namely, the impact of monetary policy actions on real output, inflation and cross-country inflation differentials, and asset prices. See, for instance, Arestis et al. (2014) and Georgiadis (2014).
} 
Taylor rule would allow one to track the trade-off between price and financial stability that confronts the central bank and the risk-taking channel of monetary policy (Borio and Zhu, 2008; Adrian and Shin, 2010a, 2010b).

Other pieces of research emphasised that financial stability may not be achieved simply via "financial cycle-augmented" Taylor rules, with interest rates rising above what is warranted by macroeconomic prospects (Turner, 2017, 2018). Therefore, considerations about asset price bubbles, financial fragility and too rapid or imprudent credit growth, among others, to specifically limit the procyclicality of the financial system, target systemic risk and mitigate its macroeconomic costs would be part of the macro-prudential policy toolkit (Papademos, 2009; Borio, 2018; Łupiński, 2018). Despite this, a number of challenges remain unsolved including: (i) how regulatory policies may themselves fail to account for continuous changes in the financial system accruing to globalisation, preferences, technology shifts (Claessens, 2016; Reinhart and Sowerbutts, 2018); (ii) whether responsibility for macro-prudential policies should be pursued by specialized prudential regulators and supervisors or monetary authorities (Rotemberg, 2014; Allen, 2015; Kenç, 2016; Ingves, 2017); (iii) how to coordinate and calibrate monetary policy and macro-prudential policies (Turner, 2018); (iii) the complacency about bond market liquidity "illusion", the rigidity of bank liquidity rules and the virtual absence of macro-prudential tools targeting the non-bank system (Turner, 2017). Summing up, there is neither consensus, nor a unified institutional supervision framework for the financial system (Barwell, 2018).

Since the Great Recession, there has also been an increasing interest in understanding how central banks' actions impact the balance sheet dynamics of financial intermediaries (Adrian and Shin, 2010a, 2010b). In theory, these non-bank entities might either dampen or amplify the effects of monetary policy. On the one hand, they can work in partnership with traditional banks in lending money. On the other hand, they may magnify the transmission of monetary policy if their risk appetite is more sensitive to changes in the interest rate (IMF, 2016). Indeed, financial intermediaries do not react to monetary policy in the same manner (Nelson et al., 2018). Hence, 
understanding this dynamics is relevant from a policy perspective, as the role of market-based financial intermediaries (e.g. brokers and dealers and shadow banks) has significantly increased over time. These institutions lack access to public liquidity sources, but they became important funding providers by translating long-term, opaque and risky assets into short-term liabilities (Pozsar et al., 2010). They also display high leverage ratios, pro-cyclical balance sheets, and strong reliance on short-term funding (Adrian and Shin, 2009; Duffie, 2010).

Nevertheless, the literature on this topic is still very scarce. Only a few studies quantify the impact of monetary policy actions on the balance sheet of market-based financial intermediaries. From a theoretical point of view, an overheated economy might lead the central bank to increase interest rates and tighten money market conditions. This would cause a drop in the asset growth of those non-bank financial intermediaries. From an empirical perspective, Angeloni et al. (2015) find that monetary policy shocks have a significant effect on different measures of bank risks. Loutskina (2011) highlights that while securitization activity since the early 2000s may have reduced the impact of interest rates on banks' credit origination, monetary policy transmission appears to have been dampened by changes in financial regulation since the crisis, as these neutralised the risk appetite of bank financial intermediaries and set the path for a more prominent role by non-bank financial intermediaries (IMF, 2016). In order to reduce the need of new equity issuance, banks more engaged in maturity transformation, with a positive duration gap, and relying less on financial derivatives to hedge interest rate risk are also more likely to forgo new lending opportunities or reduce lending when faced with a monetary policy tightening that negatively impacts on their profits (Flannery, 1981; van den Heuvel, 2017). Nelson et al. (2018) show that unexpected monetary contractions reduce the asset growth of commercial banks and expand the asset growth of shadow banks - as securitization activity rises -, even though the contribution of monetary policy surprises to the overall financial sector asset growth has been small. In the United States, securities broker-dealers seem to be less responsive to monetary policy than banks but only money market funds show contrarian responses (Igan et al., 2013). However, den Haan and Sterk (2011) notice 
that monetary tightening actually increases asset holdings of nonbank financial institutions. Mallick et al. (2017) show that both expansionary conventional (i.e. an interest rate cut) and unconventional (i.e. an increase in bond purchases) monetary policies lead to a fall in the term premium. However, while the latter does not boost economic activity, the former has a positive impact on real economic activity. Importantly, the leverage ratio of non-bank financial intermediaries (such as, securities' brokers and dealers) behaves differently depending on the period under consideration. For instance, in contrast with the pre-crisis period, bond dealers' leverage falls after an expansionary unconventional monetary policy shock, which suggests a less prominent role for market-making in bond markets.

Yet, there is still a relevant gap in the literature concerning the response of central banks to developments in those balance sheets and the opportunity to include them in the design of monetary policy measures. For instance, the asset growth rate of shadow banks can be thought as a proxy for financial sector conditions. When these worsen, economic theory would suggest that the central bank reacts by cutting interest rates, as this would alleviate financial stress. Thus, the following questions emerge: does monetary policy 'lean against the wind' vis-à-vis the growth in size of securities' brokers and dealers and shadow banks? Are financial stability concerns - in addition to the mandate of achieving medium- to long-term price stability - part of the central bank's reaction function (Manna, 2018)? These are open questions that we empirically address in the current paper.

In this study, we assess the response of the central bank to the growth rate of the size of nonbank financial intermediaries. Using quarterly data for the U.S. over the period 1946:Q1-2016Q4, we find that an increase in the asset growth of securities' brokers and dealers and shadow banks leads to a rise in the federal funds rate, as it is perceived as posing financial stability risks.

This evidence based on a single-equation framework relying on a Dynamic Ordinary Least Squares (DOLS) approach that allows us to control for potential endogeneity in the relationship between the central bank policy rate and its main drivers is also confirmed by multi-equation econometric models. In this context, we use a Bayesian Structural Vector Autoregressive (BSVAR) 
model, which provides a more robust assessment of the uncertainty about the identification and impact of monetary policy shocks than the traditional (frequentist) SVAR framework. Thus, we show that an unexpected increase in the federal funds rate leads to an immediate fall in both the asset growth rate of securities' brokers and dealers and the asset growth rate of the shadow banking sector, as liquidity tightening strikes money market conditions. However, this response later becomes positive, as non-bank financial intermediaries might intensify their securitization activity.

Finally, in light of the possibility of asymmetries and nonlinearities, we estimate the monetary policy reaction function through the lens of a Markov-Switching Vector Autoregressive (MSVAR) model. This multi-equation modelling approach is particularly well suited to capture nonlinearity in the response of the monetary authority to key macro-financial determinants accruing to specific events or structural policy changes. Our MSVAR model shows that the link between the federal funds rate and the asset growth rate of non-bank financial intermediaries can, indeed, be regime-dependent. Thus, while monetary policy is generally neutral vis-à-vis the size of these financial intermediaries, the collapse in the assets' growth rate of securities' brokers and dealers and shadow banks is associated with a policy rate decline in times of crises.

The main implication of this research is that the central bank appears to include both price and financial stability concerns in its monetary policy reaction function, by using the short-term policy rate as the policy instrument and following an augmented-version of the Taylor rule.

The rest of the paper is organized as follows. Section 2 discusses the econometric methodology and describes the data. Section 3 provides the empirical results. Finally, Section 4 concludes.

\section{Econometric Methodologies and Data}

\subsection{Single-Equation Framework}

We start by estimating an extended version of the Taylor rule using the Dynamic Ordinary Least Squares (DOLS) approach. This allows us to control for the impact of regressors' endogeneity 
on the distribution of the least squares estimator (Stock and Watson, 1993), as well as the presence of heteroscedasticity and autocorrelation in the data. More specifically, we consider the following equations

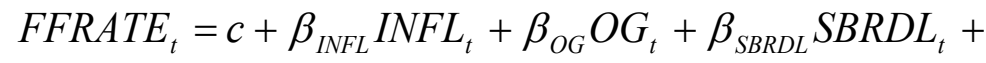

$$
\begin{aligned}
& +\sum_{i=-k}^{k} \beta_{\Delta I N F L, i} \Delta I N F L_{t+i}+\sum_{i=-k}^{k} \beta_{\Delta O G, i} \Delta O G_{t+i}+\sum_{i=-k}^{k} \beta_{\Delta S B R D L, i} \Delta S B R D L_{t+i}+\varepsilon_{\mathrm{t}}, \\
& \text { FFRATE }_{t}=c+\beta_{\text {INFL }} I N F L_{t}+\beta_{O G} O G_{t}+\beta_{\text {SHADBNK }_{\text {SHADBNK }}+}+ \\
& +\sum_{i=-k}^{k} \beta_{\Delta I N F L, i} \Delta I N F L_{t+i}+\sum_{i=-k}^{k} \beta_{\Delta O G, i} \Delta O G_{t+i}+\sum_{i=-k}^{k} \beta_{\Delta S H A D B N K, i} \Delta S H A D B N K_{t+i}+\varepsilon_{\mathrm{t}},
\end{aligned}
$$

where $F F R A T E_{t}$ is the federal funds rate, INFL $L_{t}$ is the inflation rate, $O G_{t}$ is the output gap, $S B R D L_{t}$ is the growth rate of the assets of securities' brokers and dealers, SHADBNK $_{t}$ is the growth rate of the assets of the shadow banking sector, $\Delta$ denotes the first difference operator, $c$ is a constant, $k$ is the number of leads and lags of the explanatory variables, and $\varepsilon_{\mathrm{t}}$ is the error term. ${ }^{4}$ The parameters, $\beta_{\text {INFL }}, \beta_{O G}, \beta_{S B R D L}$ and $\beta_{\text {SHADBNK }}$ denote the response of the policy instrument to the inflation rate, the output gap, the growth rate of the assets of securities' brokers and dealers and the growth rate of the assets of the shadow banking sector, respectively. The inclusion of the sum of the leads and lags of the first differences of regressors constitutes the best approximation to the instrumental variables approach and it enables us to control for endogeneity.

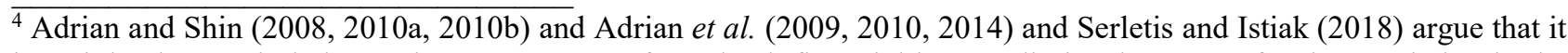
is mainly changes in balance sheet aggregates of non-bank financial intermediaries that proxy for time-variation in the marginal utility of wealth in different states of the world, as these investors are the ones who actively and aggressively adjust their risk exposures. Therefore, we include the size dynamics of non-bank financial intermediaries in the monetary policy reaction function, but not the variation in the asset growth of bank financial intermediaries. Despite this, we have also compared four versions of the Taylor rule: (i) one with the asset growth rate of securities' brokers and dealers only (i.e. our baseline model specification); (ii) another one with the asset growth rate of both securities' brokers and dealers and commercial banks; (iii) one with the asset growth rate of shadow banks only (i.e. our baseline model specification); and (iv) another one with the asset growth rate of both shadow banks and dealers and commercial banks. While the coefficient associated with the asset growth rate of the non-bank financial intermediaries is positive and statistically significant across all model specifications, the coefficient associated with the asset growth rate of commercial banks is generally not significant. For this reason, the results are not reported in the paper, but they are available from the authors upon request.
} 
For the purpose of comparison, we also consider these modified versions of the Taylor rule allowing for inertia and with the various regressors entering in lag terms. Finally, we estimate the standard Taylor rule with and without inertia.

To further control for the presence of endogeneity in our model, we also employ an efficient IV-GMM estimator, where heteroscedasticity and autocorrelation are controlled for using the HAC procedure. In this context, we estimate models (1) and (2) without the leads and lags of the explanatory variables among the set of regressors. As we are using time-series, autocorrelation should be a concern, hence the HAC procedure is suitable to deal with these issues.

\subsection{Multi-Equation Frameworks}

\subsubsection{BSVAR model}

In this Section, we consider multi-equation frameworks where all variables are treated as endogenous. We start by looking at the following Bayesian Structural VAR (BSVAR) model, which implies the existence of a linear monetary policy reaction function:

$$
\begin{gathered}
\underbrace{\Gamma(\boldsymbol{L}) \underbrace{\boldsymbol{X}_{t}}_{\boldsymbol{n} \times 1}}_{\boldsymbol{n} \times \boldsymbol{n}}=\Gamma_{0} \boldsymbol{X}_{t}+\Gamma_{1} \boldsymbol{X}_{t-1}+\ldots=\boldsymbol{c}+\varepsilon_{t} \\
v_{t}=\Gamma_{0}^{-1} \varepsilon_{\mathrm{t}},
\end{gathered}
$$

where $\varepsilon_{t} \mid X_{s}, s<t \sim \mathrm{N}(0, \Lambda), \Gamma(L)$ is a matrix-valued polynomial in the positive powers of the lag operator $L, n$ is the number of endogenous variables, $\varepsilon_{\mathrm{t}}$ is the vector of the fundamental shocks spanning the space of innovations to $X_{t}$, and $v_{t}$ is the vector of VAR innovations. ${ }^{5}$

The monetary policy can be characterized as

$$
\text { FFRATE } E_{t}=f\left(\Omega_{t}\right)+\varepsilon_{t}^{\text {FFRATE }}
$$

\footnotetext{
5 There are several advantages of the BSVAR model relative to the traditional (frequentist) SVAR model. First, it allows us to better tackle econometric problems emerging from over-fitting due to a large number of parameters, a short data sample, or a weak information set. Second, it improves the identification of monetary policy shocks, given that the analysis does not depend on a "true" parameter set or specific estimator's sampling distribution and statistical inference. Third, it provides an enhanced assessment of the uncertainty surrounding the (probability) distribution of the impulseresponse functions. Compared to single-equation frameworks, the BSVAR model also quantifies the reaction of a vector of endogenous variables (and not just a single factor) to policy rate shocks.
} 
where $F_{F R A T E}$ is the central bank's target (policy) interest rate, $f$ is a linear function, $\Omega_{t}$ is the information set, and $\varepsilon_{t}^{\text {FFRATE }}$ is the interest rate shock.

In line with the works of Christiano et al. (2005), Leeper and Zha (2003) and Sims and Zha (2006a, 2006b), Sousa (2010), Agnello et al. (2012), Jawadi et al. (2014, 2017) and Hammoudeh et al. (2015), we focus on a recursive identification scheme. Thus, we include the asset growth rate of securities' brokers and dealers or the asset growth rate of the shadow banking sector in the set of variables that reacts contemporaneously to the monetary policy shock. By contrast, the output gap and the inflation rate respond to the monetary policy shock with a lag. Therefore, the vector of endogenous variables can be expressed as $X_{t}=\left[\mathrm{OG}_{\mathrm{t}}, \mathrm{NNFL}_{\mathrm{t}}, \mathrm{FFRATE}_{\mathrm{t}}, \mathrm{SBRDL}_{\mathrm{t}}\right]$ 'or $X_{t}=\left[\mathrm{OG}_{\mathrm{t}}, \mathrm{INFL}_{\mathrm{t}}, \mathrm{FFRATE}_{\mathrm{t}}, \mathrm{SHADBNK}_{\mathrm{t}}\right]$. The asset growth of non-bank financial intermediaries responds contemporaneously to all sources of shocks. Then, the federal funds rate is placed in the system, as a proxy for the monetary policy instrument. And we include the variables that respond to the interest rate shock with a lag in the following order: 1) the inflation rate, as prices react faster than quantities; 2) the output gap, which is slower to adjust and completes the formulation of the standard Taylor rule.

Finally, we assess theuncertainty about the distribution of the impulse-response function by using a Monte Carlo Markov-Chain (MCMC) algorithm. Therefore, we construct probability intervals by drawing from the Normal-Inverse-Wishart posterior distribution of $B(L)$ and $\Sigma$ :

$$
\begin{aligned}
& \left.\beta\right|_{\Sigma} \sim \mathrm{N}\left(\hat{\beta}, \Sigma \otimes\left(X^{\prime} X\right)^{-1}\right) \\
& \Sigma^{-1} \sim \operatorname{Wishart}\left((T \hat{\Sigma})^{-1}, T-m\right)
\end{aligned}
$$

where $B(L)$ is a matrix-valued polynomial in positive powers of the lag operator $L$ associated with the regression coefficients, $\beta$ is the vector of regression coefficients in the VAR system, $\Sigma$ is the covariance matrix of the residuals, $\hat{\beta}$ and $\hat{\Sigma}$ are the corresponding maximum-likelihood posterior 
estimates at the mean, $X$ is the matrix of regressors, $T$ is the sample size and $m$ is the number of estimated parameters per equation. ${ }^{6}$

\subsubsection{MSVAR model}

An alternative approach for the estimation of the monetary policy reaction function consists of the formulation of a Markov-Switching VAR (MS-VAR) model. This methodology is particularly useful at capturing potential asymmetry and nonlinearity in the monetary policy rule, with the basic idea being that it may be subject to regime shifts associated with events, such as financial crises (Jeanne and Masson, 2000; Hamilton, 2005), or abrupt changes in economic policy (Hamilton, 1988; Davig, 2004; Sims and Zha, 2006a, 2006b). In this context, the MSVAR approach has the advantage of studying the relationship between the federal funds rate and its drivers and their interactions in a nonlinear multi-equation framework.

The less restrictive MS-VAR specification is the one where the intercept (or mean), the autoregressive coefficients and the variance-covariance matrix are conditional on the unobservable variable $s_{t}$, which indicates the regime prevailing at time $t$

$$
Y_{t}=\left\{\begin{array}{ccc}
A_{01}+\sum_{i=1}^{p} A_{i 1} Y_{t-i}+\Sigma_{1}^{\frac{1}{2}} e_{t} & \text { if } & s_{t}=1 \\
: & \text { with } e_{t} \sim N I D\left(0, I_{k}\right) \\
: & & \\
A_{0 M}+\sum_{i=1}^{p} A_{i M} Y_{t-i}+\Sigma_{1}^{\frac{1}{2}} e_{t} & \text { if } & s_{t}=M
\end{array}\right.
$$

where $Y_{t}$ is the $k$-dimensional time-series, $M$ stands for the number of regimes and $p$ for the number of lags of the autoregressive terms to take into account. Each regime is characterized by an intercept $A_{01}$, autoregressive parameter matrices $A_{i 1}, \ldots A_{i p}$, and a variance-covariance matrix $\Sigma_{i}$. All parameters switch across regimes according to a hidden Markov chain. The unobservable

\footnotetext{
${ }^{6}$ Following Sims and Zha (1999), we use a Normal-Wishart prior type. However, we set the weight on the "copersistence" prior dummy observations, which expresses the belief that when all variables are at a fixed initial level, they tend to stay there, as being equal to 0.5 . This is consistent with stationarity and with nonstationarity with or without cointegration. Such prior implies that large constants are unlikely if unit roots are present. We also set the weight on the "own persistence" prior dummy observations, which expresses the belief that when the endogenous variables have been stable at their initial levels, they will tend to persist at that level, regardless of the values of other variables, as being equal to 2. Sims and Zha (1999) emphasize that this is a reasonable guess.
} 
realization of the regime $s_{t} \in\{1, \ldots, M\}$ is governed by a discrete-state Markov stochastic process, which is defined by transition probabilities:

$$
p_{i j}=\operatorname{Pr}\left(s_{t+1}=j \mid s_{t}=i\right), \quad \sum_{j=1}^{M} p_{i j}=1, \quad \forall i, j \in\{1, \ldots, M\}
$$

More precisely, it is assumed that $s_{t}$ follows an irreducible ergodic $M$-state Markov process with the transition matrix

$$
P=\left[\begin{array}{ccc}
p_{11} & \cdots & p_{1 M} \\
\vdots & \ddots & \vdots \\
p_{M 1} & \cdots & p_{M M}
\end{array}\right]
$$

where $p_{i M}=1-p_{i 1}-p_{i 2}-\cdots-p_{i M-1}$ for $i=1, \ldots, M$. Following Hamilton (1990), the model is estimated by Maximum likelihood (ML) using an Expectation-Maximization (EM) algorithm. ${ }^{7}$

In our study, $Y_{t}$ is a $(4 \mathrm{x} 1)$ vector of endogenous variable including: (i) the federal funds rate $\left(F F R A T E_{t}\right)$; (ii) the output gap $\left(O G_{t}\right)$; (iii) the inflation rate $\left(I N F L_{t}\right)$; and (iv) the growth rate of assets held by securities' brokers and dealers $\left(S B R D L_{t}\right)$ or the shadow banking sector $\left(S H A D B N K_{t}\right)$.

We assume that $M=2$ (i.e. two regimes) and all the parameters of the model are allowed to switch across regimes. This latter assumption accounts for shifts in the conduct of U.S. monetary policy (Agnello et al., 2015) and also documented during the Great Moderation (Benati and Surico, 2009). Finally, we remove the stringent assumption of homoscedasticity in the error structure.

\subsection{Data}

We use quarterly data for the U.S. over the period 1946:Q1-2016Q4. The policy instrument is proxied by the federal funds rate, which is collected from the Board of Governors of the Federal Reserve System.

The annualized inflation rate (at quarterly frequency) is computed using data for the implicit GDP deflator that is generated via the information about nominal and real GDP. Data are gathered from the Bureau of Economic Analysis (BEA). The output gap is computed using data for real

\footnotetext{
${ }^{7}$ Krolzig (1997) provides an overview of alternative numerical techniques for the maximum likelihood estimation of MS-VAR models.
} 
GDP, which is obtained from the BEA. This is transformed into natural log terms and the HodrickPrescott filter is applied to generate the output gap in percentage of potential output. ${ }^{8}$

Finally, as in Adrian and Shin (2008, 2010a, 2010b), Adrian et al. (2010, 2014), Berrospide and Edge (2010) and Nelson et al. (2018), we construct the growth rate of assets of securities' brokers and dealers and the growth rate of assets of the shadow banking sector. We collect data from the Flow of Funds Accounts of the Board of Governors of the Federal Reserve System.

Securities' brokers and dealers are treated separately from shadow banks, which include three types of financial intermediaries: 1) finance companies; 2) issuers of asset-backed securities (ABS); and 3) funding corporations. ${ }^{9}$ Finance companies generate loans in a way that is similar to that of commercial banks. They are financial intermediaries of "information-problematic" borrowers and are typically involved in larger risk-taking behaviour than commercial banks (Carey et al., 1998). Issuers of asset-backed securities are special purpose vehicles (SPVs) that hold pools of loans and use them as collateral in their issuances. Funding corporations include subsidiaries of foreign bank and non-bank financial firms that raise funds in the commercial paper market and transfer them to foreign parent companies abroad or their banking offices in the U.S..

\section{Empirical Results}

\subsection{Single-Equation Framework}

A summary of the results using the DOLS approach can be found in Table 1. Columns 1-2 present the findings associated with the estimation of the extended version of the Taylor rule, which includes the asset growth of securities' brokers and dealers, $S B R D L$ (Column 1) and the asset

\footnotetext{
${ }^{8}$ For an overview of the challenges concerning the measurement of the output gap and the identification of conditions under which it is exceeded, see Field (2015).

${ }^{9}$ Following Meeks et al. (2017) and Nelson et al. (2018), we have also considered an alternative definition of shadow banks that includes not only 1) finance companies, 2) issuers of asset-backed securities (ABS), and 3) funding corporations, but also 4) government-sponsored enterprises (GSEs), and 5) agency- and GSE- backed mortgage pools (MtgPools). The main results concerning the estimation of monetary policy reaction functions is qualitatively and quantitatively similar across the two definitions of the shadow banking sector. It is available from the authors upon request.
} 
growth of the shadow banking sector, SHADBNK (Column 2). ${ }^{10}$ In Columns 3-4, we consider similar extended versions of the Taylor rule, but also allow for inertia, i.e. we add the lagged federal funds rate to the set of explanatory variables. In Columns 5-6, we consider all regressors in lagged terms. Finally, Columns 7-8 report the standard Taylor rules without and with inertia, respectively.

Table 1: Monetary policy and shadow banking - DOLS model.

\begin{tabular}{|c|c|c|c|c|c|c|c|c|}
\hline & (1) & (2) & (3) & (4) & (5) & (6) & (7) & (8) \\
\hline INFL & $\begin{array}{c}0.9112^{* * *} \\
{[11.017]}\end{array}$ & $\begin{array}{l}1.0810^{* * *} \\
{[12.813]}\end{array}$ & $\begin{array}{c}0.1740^{* * *} \\
{[2.878]}\end{array}$ & $\begin{array}{c}0.1974^{* * *} \\
{[3.258]}\end{array}$ & & & $\begin{array}{l}1.2691^{* * *} \\
{[13.724]}\end{array}$ & $\begin{array}{c}0.1722^{* * *} \\
{[2.878]}\end{array}$ \\
\hline$O G$ & $\begin{array}{c}0.6330^{* * *} \\
{[3.397]}\end{array}$ & $\begin{array}{l}0.3651^{*} \\
{[1.869]}\end{array}$ & $\begin{array}{c}0.2499^{* *} \\
{[2.108]}\end{array}$ & $\begin{array}{c}0.2657^{* *} \\
{[2.354]}\end{array}$ & & & $\begin{array}{c}0.9205^{* * *} \\
{[4.603]}\end{array}$ & $\begin{array}{c}0.2618^{* *} \\
{[2.365]}\end{array}$ \\
\hline SBRDL & $\begin{array}{c}0.1383^{* * *} \\
{[11.133]}\end{array}$ & & $\begin{array}{c}0.0220^{* *} \\
{[2.577]}\end{array}$ & & & & & \\
\hline SHADBNK & & $\begin{array}{c}0.1793^{* * *} \\
{[12.574]}\end{array}$ & & $\begin{array}{c}0.0277^{* *} \\
{[2.567]}\end{array}$ & & & & \\
\hline L.FFRATE & & & $\begin{array}{c}0.8438^{* * *} \\
{[18.779]}\end{array}$ & $\begin{array}{c}0.8414^{* * *} \\
{[15.962]}\end{array}$ & $\begin{array}{c}0.8445^{* * *} \\
{[20.447]}\end{array}$ & $\begin{array}{c}0.8280^{* * *} \\
{[15.129]}\end{array}$ & & $\begin{array}{c}0.8880^{* * *} \\
{[24.137]}\end{array}$ \\
\hline L.INFL & & & & & $\begin{array}{c}0.1711^{* *} \\
{[2.526]}\end{array}$ & $\begin{array}{c}0.2059^{* * *} \\
{[3.146]}\end{array}$ & & \\
\hline L.OG & & & & & $\begin{array}{l}0.0654 \\
{[0.591]}\end{array}$ & $\begin{array}{l}0.0998 \\
{[1.027]}\end{array}$ & & \\
\hline L.SBRDL & & & & & $\begin{array}{c}0.0230^{* * *} \\
{[3.184]}\end{array}$ & & & \\
\hline L.SHADBNK & & & & & & $\begin{array}{c}0.0348^{* * *} \\
{[2.981]}\end{array}$ & & \\
\hline Constant & $\begin{array}{l}0.3683 \\
{[1.389]}\end{array}$ & $\begin{array}{l}-0.2627 \\
{[-1.017]}\end{array}$ & $\begin{array}{l}-0.0588 \\
{[-0.380]}\end{array}$ & $\begin{array}{l}-0.1222 \\
{[-0.938]}\end{array}$ & $\begin{array}{l}-0.0690 \\
{[-0.430]}\end{array}$ & $\begin{array}{l}-0.1546 \\
{[-1.089]}\end{array}$ & $\begin{array}{c}0.9430^{* * *} \\
{[3.141]}\end{array}$ & $\begin{array}{l}0.0013 \\
{[0.008]}\end{array}$ \\
\hline $\begin{array}{l}\text { Observations } \\
\text { R2 }\end{array}$ & $\begin{array}{c}246 \\
0.740\end{array}$ & $\begin{array}{c}246 \\
0.769\end{array}$ & $\begin{array}{c}245 \\
0.931\end{array}$ & $\begin{array}{c}245 \\
0.934\end{array}$ & $\begin{array}{c}245 \\
0.925\end{array}$ & $\begin{array}{c}245 \\
0.928\end{array}$ & $\begin{array}{c}246 \\
0.638\end{array}$ & $\begin{array}{c}245 \\
0.926\end{array}$ \\
\hline
\end{tabular}

Columns 1-2 clearly show that both the asset growth of the securities' brokers and dealers and the asset growth of the shadow banking sector enter positively and significantly in the monetary

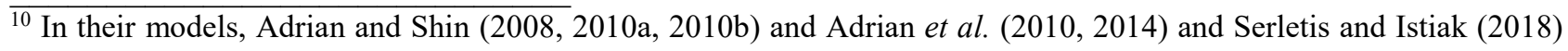
consider three measures of non-bank financial intermediaries' balance sheet changes, namely: (i) the asset growth rate of securities' brokers and dealers (or shadow banks); (ii) the equity growth rate of securities' brokers and dealers (or shadow banks); and (iii) the leverage growth rate of securities' brokers and dealers (or shadow banks). Our results show that while the asset growth rate of non-bank financial intermediaries enters positively and significantly in all model specifications, the coefficient associated with both the equity growth and the leverage growth of non-bank financial intermediaries is never significant in the models with inertia and those where all variables enter the information set of central bank in lags. Additionally, in the models without inertia, the point coefficient estimates of the equity growth and the leverage growth of non-bank financial intermediaries are statistically significant, albeit substantially smaller than the point coefficient estimates associated with the asset growth rate of non-bank financial intermediaries. Therefore, the empirical evidence corroborates our baseline model specifications, where the key balance sheet dynamics of non-bank financial intermediaries is captured by variation in the asset growth of bank financial intermediaries to which the central bank responds. These results are not reported in the paper, but they are available from the authors upon request.
} 
policy reaction function. ${ }^{11}$ This result suggests that the central bank takes into account the size of these financial intermediaries when setting up the interest rate: an increase in the asset growth of such financial intermediaries is seen as posing financial stability risks and inflationary pressures, thus, the federal funds rate is raised. Similar evidence is obtained when we allow for inertia in the conduct of monetary policy (Columns 3-4), as both the asset growth of the securities' brokers and dealers and the asset growth of the shadow banking sector keep their positive and significant coefficients.

In what concerns other regressors, we find that: (i) the coefficient associated with inflation is positive, significant and large in magnitude, suggesting that monetary policy aggressively counteracts inflationary pressures by raising the interest rate; (ii) the output gap also enters positively and significantly the monetary policy reaction function, thereby, implying that a widening of the gap between actual output and potential output is associated with inflationary pressures when output exceeds its full-employment level and, consequently, the federal funds rate is raised to mitigate them; and (iii) the coefficient associated with the lagged interest rate is also positive, relatively large in magnitude and statistically significant, thus, showing that inertia is a good characterization pattern of monetary policy conduct. ${ }^{12}$

The empirical evidence presented so far highlights that monetary policy responds to developments in the asset growth of financial intermediaries, such as securities' brokers and dealers and shadow banks. However, some authors like den Haan and Sterk (2011) and Nelson et al. (2018)

\footnotetext{
${ }^{11}$ For example, when the asset growth rate of securities' brokers and dealers and the shadow banking sector increases by one percentage point, the monetary authority raises the federal funds rate by about 0.14 and 0.18 percentage points, respectively.

12 We highlight that our frameworks are based on a time-invariant monetary policy rule with fixed-parameter coefficients. Despite this, we have also considered models with time-varying parameters using both rolling windows and recursive windows. All in all, the evidence shows that extended versions of the Taylor rule with fixed-parameter coefficients provide a good characterisation of the central bank's behaviour and its response to major macro-financial developments. Additionally, the results do not suggest that a time-varying coefficient parameter approach would outperform our fixed-coefficient parameter framework, despite the development of financial markets, the possibility of different monetary policy regimes or even the use of quantitative instruments, such as quantitative easing (instead of price instruments, such as the policy rate), in more recent times. This is in accordance with the work of Nelson et al. (2018), who rely on a time-varying vector auto-regression (TV-VAR) model, as proposed by Primiceri (2015), to show that the relationship between monetary policy and the asset growth of the financial system is stable over time. These findings are not reported in the paper, but they are available from the authors upon request.
} 
emphasize that monetary policy actions also have an impact on the growth of non-bank mortgage lending, as well as on securitization activity.

To explore this channel, we use the DOLS estimator to estimate the effect of the federal funds rate on the asset growth of the securities' brokers and dealers and the asset growth of the shadow banking sector. Basically, we swap the dependent variable with these regressors and keep the other explanatory variables of equations (1) and (2) unchanged.

The results are reported in Table 2. Columns 1-2 present the findings associated with the static model, while Columns 3-4 show the estimates for the dynamic model. In Columns 5-6, we drop the federal funds rate from the static model, while, in Columns 7-8, we drop the same variable from the dynamic model.

Table 2: Non-bank intermediaries' asset growth and monetary policy - DOLS model.

\begin{tabular}{|c|c|c|c|c|c|c|c|c|}
\hline & $(1)$ & $(2)$ & (3) & (4) & (5) & (6) & $(7)$ & $(8)$ \\
\hline & SBRDL & SHADBNK & SBRDL & SHADBNK & SBRDL & SHADBNK & SBRDL & SHADBNK \\
\hline L.SBRDL & & & $\begin{array}{c}0.6884^{* * *} \\
{[11.405]}\end{array}$ & & & & $\begin{array}{c}0.6951^{* * *} \\
{[12.958]}\end{array}$ & \\
\hline INFL & $\begin{array}{l}0.5851 \\
{[0.675]}\end{array}$ & $\begin{array}{c}-2.0847^{* * *} \\
{[-6.625]}\end{array}$ & $\begin{array}{l}0.4675 \\
{[0.734]}\end{array}$ & $\begin{array}{l}-0.1109 \\
{[-0.607]}\end{array}$ & $\begin{array}{c}2.7930^{* * *} \\
{[6.212]}\end{array}$ & $\begin{array}{c}0.9378^{* * *} \\
{[3.638]}\end{array}$ & $\begin{array}{c}0.9419^{* *} \\
{[2.391]}\end{array}$ & $\begin{array}{l}0.1370 \\
{[1.293]}\end{array}$ \\
\hline$O G$ & $\begin{array}{l}1.1085 \\
{[1.082]}\end{array}$ & $\begin{array}{c}1.9370^{* *} \\
{[2.491]}\end{array}$ & $\begin{array}{l}-0.0327 \\
{[-0.041]}\end{array}$ & $\begin{array}{l}-0.2647 \\
{[-0.871]}\end{array}$ & $\begin{array}{c}2.8476^{\star * *} \\
{[2.870]}\end{array}$ & $\begin{array}{c}3.8676^{\star * *} \\
{[4.253]}\end{array}$ & $\begin{array}{l}0.1573 \\
{[0.195]}\end{array}$ & $\begin{array}{l}-0.2837 \\
{[-0.906]}\end{array}$ \\
\hline FFRATE & $\begin{array}{c}2.0113^{* * *} \\
{[4.371]}\end{array}$ & $\begin{array}{c}2.5276^{* * *} \\
{[11.730]}\end{array}$ & $\begin{array}{l}0.4935 \\
{[1.351]}\end{array}$ & $\begin{array}{l}0.1762 \\
{[1.333]}\end{array}$ & & & & \\
\hline L.SHADBNK & & & & $\begin{array}{c}0.9167^{* * *} \\
{[28.557]}\end{array}$ & & & & $\begin{array}{c}0.9333^{* * *} \\
{[36.378]}\end{array}$ \\
\hline L.INFL & & & & & & & & \\
\hline L.OG & & & & & & & & \\
\hline L.FFRATE & & & & & & & & \\
\hline Constant & $\begin{array}{l}0.1954 \\
{[0.120]}\end{array}$ & $\begin{array}{c}3.9670^{* * *} \\
{[3.954]}\end{array}$ & $\begin{array}{l}-0.2282 \\
{[-0.197]}\end{array}$ & $\begin{array}{l}0.2062 \\
{[0.498]}\end{array}$ & $\begin{array}{c}3.5966^{* *} \\
{[2.185]}\end{array}$ & $\begin{array}{c}7.2065^{* * *} \\
{[6.384]}\end{array}$ & $\begin{array}{l}0.7394 \\
{[0.623]}\end{array}$ & $\begin{array}{l}0.1499 \\
{[0.347]}\end{array}$ \\
\hline $\begin{array}{l}\text { Observations } \\
\text { R2 }\end{array}$ & $\begin{array}{c}241 \\
0.417\end{array}$ & $\begin{array}{c}241 \\
0.523\end{array}$ & $\begin{array}{c}241 \\
0.684\end{array}$ & $\begin{array}{c}241 \\
0.919\end{array}$ & $\begin{array}{c}252 \\
0.335\end{array}$ & $\begin{array}{c}252 \\
0.266\end{array}$ & $\begin{array}{c}251 \\
0.655\end{array}$ & $\begin{array}{c}251 \\
0.907\end{array}$ \\
\hline
\end{tabular}

In line with the work of Nelson et al. (2018), we find that a rise in the federal funds rate is associated with an acceleration of the activity of non-bank intermediaries: the coefficient associated with the federal funds rate is positive and significant in both the equation for the asset growth of the securities' brokers and dealers and the equation for the asset growth of the shadow banking sector, 
even though the results are stronger in the case of the static model (Columns 1-2) than the dynamic framework (Columns 3-4). Thus, shadow banks tend to counteract the intensification of liquidity constraints imposed by tightening monetary policy actions with a potential rise in securitization activity and there may be a tendency for the migration of lending from the activity that is regulated by the central bank to the rather opaque investment banking sector.

As for the other explanatory variables, the results suggest that: (i) an increase in inflation typically has a positive effect on the activity of the financial intermediaries under analysis; (ii) the coefficient associated with the output gap is also positive, although its statistical significance is weak; and (iii) the asset growth of the financial intermediaries displays strong persistence. The positive link between inflation and the activity of non-bank financial intermediaries suggests that the profits of these institutions thrive during periods of high inflation when monetary illusion is more likely to occur.

A summary of the results using the IV-GMM estimator can be found in Table 3. The tests point to the presence of heteroscedasticity in all specifications. As we are using time series, autocorrelation should be a concern, hence the HAC procedure is suitable to deal with these issues. In addition, four lags of $I N F L_{t}$ and $O G_{t}$ are used as instruments for these variables; the second lag of the federal funds rate $\left(F F R A T E_{t}\right)$ is also used as an instrument for its lag, when it is included in the equation; the other variables have proved to be exogenous according to the $C$-statistic (differencein-Sargan statistic). The tests also reveal the presence of endogeneity and corroborate the validity of the over-identification restrictions/instruments (Hansen- $J$ statistic). The Cragg-Donald statistic shows that the instruments are not weak: the respective statistics are always higher that the $5 \%$ Stock-Yogo critical values. Hence, these tests sustain the use of this IV-GMM approach.

We start by presenting the results for the static model, where all variables are contemporaneous and the lag of the dependent variable is not considered. Columns 1-2 show that both the asset growth of the securities' brokers and dealers and the asset growth of the shadow banking sector enter positively and significantly in the monetary policy reaction function. This 
suggests that the central bank takes into account the size of these financial intermediaries when setting up the interest rate: an increase in the asset growth of such financial intermediaries is seen as posing financial stability risks, thus, the federal funds rate is raised. Similar evidence is obtained when we allow for inertia in monetary policy, as both the asset growth of the securities' brokers and dealers and the asset growth of the shadow banking sector remain positive and significant. This shows that the monetary authority tries to tackle not only inflationary pressures, but also financial imbalances arising from the increase in the size of non-bank financial intermediaries.

Table 3: Monetary policy and shadow banking - IV/GMM HAC model.

\begin{tabular}{|c|c|c|c|c|c|c|c|c|}
\hline & (1) & (2) & (3) & (4) & (5) & (6) & (7) & (8) \\
\hline INFL & $\begin{array}{l}1.1507^{* * *} \\
(0.1197)\end{array}$ & $\begin{array}{l}1.1740^{* * *} \\
(0.1323)\end{array}$ & $\begin{array}{l}0.1467^{* * *} \\
(0.0479)\end{array}$ & $\begin{array}{c}0.1977^{* * *} \\
(0.0499)\end{array}$ & & & $\begin{array}{l}1.2636^{* * *} \\
(0.1268)\end{array}$ & $\begin{array}{l}0.1558^{* * *} \\
(0.0463)\end{array}$ \\
\hline$O G$ & $\begin{array}{c}0.5807^{* * *} \\
(0.1661)\end{array}$ & $\begin{array}{c}0.1070 \\
(0.1684)\end{array}$ & $\begin{array}{l}0.1472^{* *} \\
(0.0583)\end{array}$ & $\begin{array}{c}0.0966 \\
(0.0677)\end{array}$ & & & $\begin{array}{c}0.5049^{* * *} \\
(0.1781)\end{array}$ & $\begin{array}{l}0.1429^{* *} \\
(0.0596)\end{array}$ \\
\hline$S B R D L$ & $\begin{array}{c}0.0401^{* * *} \\
(0.0110)\end{array}$ & & $\begin{array}{c}0.0032 \\
(0.0039)\end{array}$ & & & & & \\
\hline SHADBNK & & $\begin{array}{c}0.1332^{* * *} \\
(0.0172)\end{array}$ & & $\begin{array}{l}0.0202^{* *} \\
(0.0099)\end{array}$ & & & & \\
\hline L.FFRATE & & & $\begin{array}{c}0.8888^{* * *} \\
(0.0346)\end{array}$ & $\begin{array}{c}0.8569 * * * \\
(0.0496)\end{array}$ & $\begin{array}{c}0.8847^{* * *} \\
(0.0403)\end{array}$ & $\begin{array}{c}0.8647^{* * *} \\
(0.0546)\end{array}$ & & $\begin{array}{c}0.8959^{* * *} \\
(0.0332)\end{array}$ \\
\hline L.INFL & & & & & $\begin{array}{c}0.1385^{* * *} \\
(0.0522)\end{array}$ & $\begin{array}{c}0.1962^{* * *} \\
(0.0569)\end{array}$ & & \\
\hline L.OG & & & & & $\begin{array}{l}0.1164^{*} \\
(0.0619)\end{array}$ & $\begin{array}{c}0.0607 \\
(0.0618)\end{array}$ & & \\
\hline L.SBRDL & & & & & $\begin{array}{l}0.0076^{*} \\
(0.0042)\end{array}$ & & & \\
\hline L.SHADBNK & & & & & & $\begin{array}{l}0.0178^{*} \\
(0.0098)\end{array}$ & & \\
\hline Constant & $\begin{array}{l}0.8012^{* *} \\
(0.3591)\end{array}$ & $\begin{array}{l}-0.0578 \\
(0.3453)\end{array}$ & $\begin{array}{c}0.0630 \\
(0.1339)\end{array}$ & $\begin{array}{l}-0.0880 \\
(0.1116)\end{array}$ & $\begin{array}{c}0.0663 \\
(0.1358)\end{array}$ & $\begin{array}{l}-0.0772 \\
(0.1115)\end{array}$ & $\begin{array}{c}0.0471 \\
(0.1350)\end{array}$ & $\begin{array}{c}0.0522 \\
(0.1377)\end{array}$ \\
\hline Observations & 250 & 250 & 248 & 248 & 249 & 249 & 248 & 249 \\
\hline$R^{2}$ & 0.6126 & 0.6778 & 0.9093 & 0.9095 & 0.9043 & 0.9024 & 0.9085 & 0.9017 \\
\hline Endog. Test & $\begin{array}{c}7.270 \\
{[0.0264]}\end{array}$ & $\begin{array}{c}7.381 \\
{[0.0250]}\end{array}$ & $\begin{array}{c}7.901 \\
{[0.0481]}\end{array}$ & $\begin{array}{c}8.506 \\
{[0.0366]}\end{array}$ & $\begin{array}{c}11.280 \\
{[0.0103]}\end{array}$ & $\begin{array}{c}12.116 \\
{[0.0070]}\end{array}$ & $\begin{array}{c}5.310 \\
{[0.070]}\end{array}$ & $\begin{array}{c}6.040 \\
{[0.1097]}\end{array}$ \\
\hline Overid. Test & $\begin{array}{c}7.273 \\
{[0.2963]}\end{array}$ & $\begin{array}{c}11.223 \\
{[0.0817]}\end{array}$ & $\begin{array}{c}2.425 \\
{[0.8768]}\end{array}$ & $\begin{array}{c}3.938 \\
{[0.6851]}\end{array}$ & $\begin{array}{c}3.236 \\
{[0.5191]}\end{array}$ & $\begin{array}{c}4.201 \\
{[0.3794]}\end{array}$ & $\begin{array}{c}8.150 \\
{[0.2273]}\end{array}$ & $\begin{array}{c}2.910 \\
{[0.8201]}\end{array}$ \\
\hline $\begin{array}{l}\text { Weak id. test } \\
\text { S-Y } 5 \% \text { c.v. }\end{array}$ & $\begin{array}{l}105.438 \\
\{17.70\}\end{array}$ & $\begin{array}{l}86.103 \\
\{17.70\} \\
\end{array}$ & $\begin{array}{l}94.226 \\
\{16.10\}\end{array}$ & $\begin{array}{l}60.801 \\
\{16.10\}\end{array}$ & $\begin{array}{c}102.705 \\
{[13.95]}\end{array}$ & $\begin{array}{l}67.245 \\
{[13.95]}\end{array}$ & $\begin{array}{l}103.783 \\
\{17.70\}\end{array}$ & $\begin{array}{l}91.106 \\
\{16.10\}\end{array}$ \\
\hline
\end{tabular}

Notes: Robust standard errors in parentheses ${ }^{* * *} p<0.01,{ }^{* *} p<0.05,{ }^{*} p<0.1$. Heteroscedasticity and autocorrelation are controlled for using the HAC procedure for the IV/GMM estimator. Four lags of inflation and output gap are used as instruments for these variables; the second lag of the federal funds rate is also used as instrument for its lag, when included; the other variables have proved to be exogenous according to the $C$-statistic (difference-in-Sargan statistic). For endogeneity and over-identification, we report the statistics and $p$-values (in squared brackets) of Sargan-Hansen J-tests. The Cragg-Donald Wald $F$-statistic is reported for the weak identification test, as well as the Stock-Yogo critical values at $5 \%$ in brackets (maximal IV relative bias); the Kleibergen-Paaprk Wald $F$-statistic was also computed (not reported here), but the conclusions have shown to be similar to Cragg-Donald's.

Regarding other regressors, we find that: (i) the coefficient associated with inflation is positive, significant and large in magnitude, suggesting that monetary policy aggressively 
counteracts the inflationary pressures by raising the interest rate; (ii) the output gap also enters positively and significantly in the monetary policy reaction function, thereby, implying that a widening of the gap between actual output and potential output leads to an increase in the federal funds rate; and (iii) the coefficient associated with the lagged interest rate is also positive, relatively large in magnitude and statistically significant, thus, showing that inertia is a good characterization pattern of monetary policy conduct.

A dynamic model is employed in regressions 3 and 4, but using all contemporaneous values of other regressors. The results indicate the presence of a significant degree of persistence in this extended monetary rule, but the main conclusions remain unchanged: inflation is the most important target of the monetary authority, but it also has a great concern over the developments in the economic activity and over the growth of the shadow banking assets, in particular.

To account for the fact that monetary authorities may react to inflation and output gap with some lag (and due to the usual delay in reporting economic data), we test these extended monetary rules using the first lag of all variables (in this case, lags 2 to 4 are used as instruments to the lag of inflation and output gap; the lag of the federal funds rate is instrumented with its second lag - see Columns 5 and 6). These results appear more robust, in the sense that monetary authorities respond not only to lagged inflation and output gap, but also to the lagged effects of the asset growth of securities' brokers and dealers and the asset growth of shadow banks.

The last two columns in Table 3 show the results for a static and dynamic simple Taylor rule. Our findings corroborate the usual findings with a Taylor rule: monetary authorities respond strongly to inflation and, to a lesser degree, the output gap, which is clear when the persistence in the process is controlled for. Nevertheless, our results point out that these simple Taylor rules should be extended with information from brokers and dealers and shadow banking assets. The central bank indeed incorporates it in the decisions about the interest rate.

In sum, the standard Taylor rule helps the monetary authority to stabilize expectations about the future path of inflation and to smooth undesirable real GDP fluctuations. In addition, the 
inclusion of the dynamics of the size of the balance sheet of non-bank financial intermediaries in the monetary policy reaction function contributes to account for financial stability risks associated with the deterioration of liquidity conditions and the expansion of securitization activity.

Next, we explore further the reaction of the monetary authority by allowing for different estimators to control for endogeneity and a different set of instruments. Our benchmark model considers all regressors lagged one period and uses as instruments the lags 2 to 4 of the federal funds rate, inflation, output gap and financial variables. The results reported in Table 4 are similar to those reported in Table 3 for the dynamic lagged model: the central bank reacts strongly to inflation (and, to some extent, the output gap), and to the growth in securities' brokers and dealers and shadow banks' assets.

Table 4: Monetary policy and shadow banking - IV/GMM HAC dynamic lagged model.

\begin{tabular}{|c|c|c|c|c|c|c|c|c|}
\hline & IV-2SLS & IV-2SLS & IV-rob & IV-rob & IV-hac & IV-hac & GMM2s-hac & GMM2s-hac \\
\hline L. FFRATE & $\begin{array}{c}0.8869^{* * *} \\
(0.0361)\end{array}$ & $\begin{array}{c}0.8722^{* * *} \\
(0.0411)\end{array}$ & $\begin{array}{c}0.8869^{* * *} \\
(0.0431)\end{array}$ & $\begin{array}{c}0.8722^{* * *} \\
(0.0625)\end{array}$ & $\begin{array}{c}0.8869^{* * *} \\
(0.0424)\end{array}$ & $\begin{array}{c}0.8722^{* * *} \\
(0.0583)\end{array}$ & $\begin{array}{c}0.8717^{* * *} \\
(0.0412)\end{array}$ & $\begin{array}{c}0.8519^{* * *} \\
(0.0575)\end{array}$ \\
\hline L.INFL & $\begin{array}{l}0.1056^{*} \\
(0.0547)\end{array}$ & $\begin{array}{l}0.1224^{\star *} \\
(0.0574)\end{array}$ & $\begin{array}{c}0.1056 \\
(0.0716)\end{array}$ & $\begin{array}{c}0.1224 \\
(0.0767)\end{array}$ & $\begin{array}{c}0.1056 \\
(0.0677)\end{array}$ & $\begin{array}{c}0.1224 \\
(0.0774)\end{array}$ & $\begin{array}{c}0.1375^{\star \star *} \\
(0.0534)\end{array}$ & $\begin{array}{c}0.1921^{* * *} \\
(0.0527)\end{array}$ \\
\hline L.OG & $\begin{array}{l}0.1081^{*} \\
(0.0573)\end{array}$ & $\begin{array}{c}0.0528 \\
(0.0601)\end{array}$ & $\begin{array}{c}0.1081 \\
(0.0675)\end{array}$ & $\begin{array}{c}0.0528 \\
(0.0695)\end{array}$ & $\begin{array}{c}0.1081 \\
(0.0673)\end{array}$ & $\begin{array}{c}0.0528 \\
(0.0674)\end{array}$ & $\begin{array}{l}0.1159^{*} \\
(0.0612)\end{array}$ & $\begin{array}{c}0.0617 \\
(0.0611)\end{array}$ \\
\hline L.SBRDL & $\begin{array}{l}0.0096^{*} \\
(0.0049)\end{array}$ & & $\begin{array}{l}0.0096^{* *} \\
(0.0046)\end{array}$ & & $\begin{array}{l}0.0096^{*} \\
(0.0051)\end{array}$ & & $\begin{array}{c}0.0077^{*} \\
(0.0043)\end{array}$ & \\
\hline L.SHADBNK & & $\begin{array}{c}0.0180^{*} \\
(0.0099)\end{array}$ & & $\begin{array}{c}0.0180 \\
(0.0117)\end{array}$ & & $\begin{array}{l}0.0180^{*} \\
(0.0106)\end{array}$ & & $\begin{array}{l}0.0169^{*} \\
(0.0091)\end{array}$ \\
\hline Constant & $\begin{array}{c}0.1044 \\
(0.1353) \\
\end{array}$ & $\begin{array}{c}0.0618 \\
(0.1407) \\
\end{array}$ & $\begin{array}{c}0.1044 \\
(0.1803) \\
\end{array}$ & $\begin{array}{c}0.0618 \\
(0.1602) \\
\end{array}$ & $\begin{array}{c}0.1044 \\
(0.1508) \\
\end{array}$ & $\begin{array}{c}0.0618 \\
(0.1494) \\
\end{array}$ & $\begin{array}{c}0.0654 \\
(0.1349) \\
\end{array}$ & $\begin{array}{c}-0.0761 \\
(0.1121) \\
\end{array}$ \\
\hline $\begin{array}{l}\text { Observations } \\
\text { R-squared }\end{array}$ & $\begin{array}{c}249 \\
0.9045\end{array}$ & $\begin{array}{c}249 \\
0.9039\end{array}$ & $\begin{array}{c}249 \\
0.9045\end{array}$ & $\begin{array}{c}249 \\
0.9039\end{array}$ & $\begin{array}{c}249 \\
0.9045\end{array}$ & $\begin{array}{c}249 \\
0.9039\end{array}$ & $\begin{array}{c}249 \\
0.9021\end{array}$ & $\begin{array}{c}249 \\
0.9003\end{array}$ \\
\hline Endog. test & $\begin{array}{c}5.051 \\
{[0.1681]}\end{array}$ & $\begin{array}{c}7.245 \\
{[0.0645]}\end{array}$ & $\begin{array}{c}8.666 \\
{[0.0341]}\end{array}$ & $\begin{array}{c}8.366 \\
{[0.0390]}\end{array}$ & $\begin{array}{c}9.480 \\
{[0.0235]}\end{array}$ & $\begin{array}{c}10.446 \\
{[0.0151]}\end{array}$ & $\begin{array}{c}14.802 \\
{[0.0020]}\end{array}$ & $\begin{array}{c}12.446 \\
{[0.0060]}\end{array}$ \\
\hline Overid. test & $\begin{array}{c}2.809 \\
{[0.5903]}\end{array}$ & $\begin{array}{c}5.017 \\
{[0.2855]}\end{array}$ & $\begin{array}{c}1.409 \\
{[0.8426]}\end{array}$ & $\begin{array}{c}3.095 \\
{[0.5421]}\end{array}$ & $\begin{array}{c}1.536 \\
{[0.8203]}\end{array}$ & $\begin{array}{c}3.259 \\
{[0.5154]}\end{array}$ & $\begin{array}{c}1.536 \\
{[0.8203]}\end{array}$ & $\begin{array}{c}3.259 \\
{[0.5154]}\end{array}$ \\
\hline $\begin{array}{l}\text { Weak id. test } \\
\text { S-Y } 5 \% \text { c.v. }\end{array}$ & $\begin{array}{c}114.059 \\
{[13.95]}\end{array}$ & $\begin{array}{l}75.805 \\
{[13.95]}\end{array}$ & $\begin{array}{c}114.059 \\
{[13.95]}\end{array}$ & $\begin{array}{l}75.805 \\
{[13.95]}\end{array}$ & $\begin{array}{c}114.059 \\
{[13.95]}\end{array}$ & $\begin{array}{l}75.805 \\
{[13.95]}\end{array}$ & $\begin{array}{l}114.059 \\
{[13.95]}\end{array}$ & $\begin{array}{l}75.805 \\
{[13.95]}\end{array}$ \\
\hline
\end{tabular}

Notes: Robust standard errors in parentheses ${ }^{* * *} p<0.01,{ }^{* *} p<0.05,{ }^{*} p<0.1$. Heteroscedasticity and autocorrelation are controlled for using the HAC procedure for the IV-hac and GMM2s-hac estimators. Lags 2 to 4 for the federal funds rate, inflation, output gap and the respective financial variables are used as instruments. For endogeneity and over-identification, we report the statistics and $p$-values (in squared brackets) of Sargan-Hansen J-tests. The Cragg-Donald Wald F-statistic is reported for the weak identification test, as well as the Stock-Yogo critical values at $5 \%$ in brackets (maximal IV relative bias); the Kleibergen-Paaprk Wald F-statistic was also computed (not reported here), but the conclusions have shown to be similar to Cragg-Donald's.

Additionally, we also test for the possibility of reverse effects on the financial variables.

Hence, departing from the framework used in the estimations reported in Table 3, we replace the 
dependent variable by either the asset growth rate of securities' brokers and dealers or the asset growth rate of the shadow banking sector. The same set of instruments (and estimators) is used in the new results reported in Table 5. Nevertheless, no evidence of endogeneity is found in this case, which means that we do not need to incur in this complexity to estimate this different equation. Despite the persistence of each financial variable, only the output gap has a significant (negative) impact on the behaviour of the asset growth of securities' brokers and dealers and shadow banks. Over time, a better economic environment tends to undermine such growth.

Table 5: Non-bank intermediaries' asset growth and monetary policy - IV/GMM HAC model.

\begin{tabular}{|c|c|c|c|c|c|c|c|c|}
\hline VARIABLES & $\begin{array}{l}\text { (SBRDL) } \\
\text { IV-2SLS }\end{array}$ & $\begin{array}{c}\text { (SHADBNK) } \\
\text { IV-2SLS }\end{array}$ & $\begin{array}{l}\text { (SBRDL) } \\
\text { IV-rob }\end{array}$ & $\begin{array}{c}\text { (SHADBNK) } \\
\text { IV-rob }\end{array}$ & $\begin{array}{c}\text { (SBRDL) } \\
\text { IV-hac }\end{array}$ & $\begin{array}{c}\text { (SHADBNK) } \\
\text { IV-hac }\end{array}$ & $\begin{array}{c}\text { (SBRDL) } \\
\text { GMM2s-hac }\end{array}$ & $\begin{array}{l}\text { (SHADBNK) } \\
\text { GMM2s-hac }\end{array}$ \\
\hline \multirow[t]{2}{*}{ L.FFRATE } & 0.4410 & 0.2046 & 0.4410 & 0.2046 & 0.4410 & 0.2046 & $0.6221^{*}$ & $0.2741^{*}$ \\
\hline & $(0.3271)$ & $(0.1255)$ & $(0.3782)$ & $(0.1421)$ & $(0.3664)$ & $(0.1542)$ & $(0.3397)$ & $(0.1458)$ \\
\hline \multirow[t]{2}{*}{ L.INFL } & 0.1822 & $-0.3042^{*}$ & 0.1822 & -0.3042 & 0.1822 & -0.3042 & -0.2374 & $-0.3968^{*}$ \\
\hline & $(0.4787)$ & $(0.1725)$ & $(0.5344)$ & $(0.2113)$ & $(0.5545)$ & $(0.2245)$ & $(0.5080)$ & (0.2096) \\
\hline L.OG & $-1.6347^{* * *}$ & $0.3816^{* *}$ & $-1.6347^{* * *}$ & $0.3816^{* *}$ & $-1.6347^{* * *}$ & $0.3816^{*}$ & $-1.6266^{* * *}$ & $0.3749^{*}$ \\
\hline & $(0.5054)$ & $(0.1811)$ & $(0.5582)$ & $(0.1838)$ & $(0.5124)$ & $(0.2026)$ & $(0.5060)$ & $(0.2004)$ \\
\hline L.SBRDL & $0.7450^{* * *}$ & & $0.7450^{* * *}$ & & $0.7450^{* * *}$ & & $0.7191^{* * *}$ & \\
\hline & $(0.0555)$ & & $(0.0786)$ & & $(0.0769)$ & & $(0.0713)$ & \\
\hline L.SHADBNK & & $\begin{array}{c}0.8739 * * * \\
(0.0322)\end{array}$ & & $\begin{array}{c}0.8739 * * * \\
(0.0377)\end{array}$ & & $\begin{array}{c}0.8739 * * * \\
(0.0426)\end{array}$ & & $\begin{array}{l}0.8758^{* * *} \\
(0.0395)\end{array}$ \\
\hline Constant & $\begin{array}{c}0.2353 \\
(1.1934)\end{array}$ & $\begin{array}{l}1.1909^{* * *} \\
(0.4269)\end{array}$ & $\begin{array}{c}0.2353 \\
(1.0813)\end{array}$ & $\begin{array}{l}1.1909 * * * \\
(0.4463)\end{array}$ & $\begin{array}{c}0.2353 \\
(1.0503)\end{array}$ & $\begin{array}{l}1.1909^{* *} \\
(0.5090)\end{array}$ & $\begin{array}{c}0.7519 \\
(1.0203)\end{array}$ & $\begin{array}{l}1.0578^{* *} \\
(0.4795)\end{array}$ \\
\hline Observations & 248 & 248 & 248 & 248 & 248 & 248 & 248 & 248 \\
\hline R-squared & 0.6281 & 0.8842 & 0.6281 & 0.8842 & 0.6281 & 0.8842 & 0.6271 & 0.8843 \\
\hline \multirow[t]{2}{*}{ Endog. Test } & 1.857 & 9.047 & 1.541 & 2.563 & 0.649 & 2.423 & 0.649 & 2.423 \\
\hline & [0.7621] & [0.0599] & [0.8193] & [0.6334] & [0.9575] & [0.6585] & [0.9575] & [0.6585] \\
\hline \multirow[t]{2}{*}{ Overid. Test } & 14.535 & 42.106 & 9.601 & 31.805 & 9.064 & 26.091 & 9.064 & 26.091 \\
\hline & [0.0058] & {$[0.0000]$} & [0.0477] & [0.0000] & [0.0595] & [0.0000] & [0.0595] & [0.0000] \\
\hline \multirow{2}{*}{$\begin{array}{l}\text { Weak ID test } \\
\text { S-Y 5\% c.v. }\end{array}$} & 36.903 & 51.904 & 36.903 & 51.904 & 36.903 & 51.904 & 36.903 & 51.904 \\
\hline & [13.95] & [13.95] & [13.95] & [13.95] & [13.95] & [13.95] & [13.95] & [13.95] \\
\hline Notes & Robust stanc & errors in paren & $\operatorname{ses}^{* * *} p<0.0$ & ${ }^{\star *} p<0.05,{ }^{*} p$ & 1. Heterosced & icity and autoc & $\begin{array}{l}\text { lation are contro } \\
\text { ion, output gap } \\
\text { atistics and } p \text {-val } \\
\text { fication test, as } \\
\text { stic was also cor }\end{array}$ & $\begin{array}{l}\text { ed for } \\
\text { id the } \\
\text { es (in } \\
\text { ell as } \\
\text { puted }\end{array}$ \\
\hline
\end{tabular}

\subsection{Multi-Equation Frameworks}

\subsubsection{BSVAR model}

We identify the monetary policy shocks by imposing the recursive assumptions defined in Equation (5) and estimate the BSVAR represented by Equations (3) and (4). Figures 1-2 plot the 
impulse-response functions to a positive shock in the interest rate when we include the securities' brokers and dealers and the shadow banking sector in the system, respectively. The blue dashed line corresponds to the median response, while the red dashed lines are the $68 \%$ posterior probability bands estimated by using a Monte-Carlo Markov-Chain (MCMC) algorithm based on 50000 draws. Therefore, they are approximately one standard error above and below the central line, so that the gap between the two lines is about two standard errors.

It can be seen that an unexpected increase of 100 basis points in the federal funds rate leads to an immediate fall in the asset growth rate of securities' brokers and dealers. However, after this initial reaction, the impact on the size of the non-bank financial intermediaries becomes positive. This finding gives support to the idea that non-bank financial intermediaries quickly adjust their balance sheet exposures, for instance, in response to interest rate shocks (Adrian and Shin, 2008, 2010a, 2010b; Adrian et al., 2009, 2010, 2014; Serletis and Istiak, 2018). As for the asset growth rate of the shadow banking sector, the response to the interest rate shock is always positive, which is consistent with the increase in securitization activity associated with the rise in interest rates. In fact, the federal funds rate remains above its initial level for about 12 quarters. This positive response is in accordance with the work of Nelson et al. (2018), who uncover a "waterbed effect", that is, instead of reducing the asset growth of shadow banks, surprise monetary contractions tend to expand it.

Finally, the results also suggest that, following a contractionary monetary policy, both the output gap and the inflation rate fall, but the response comes with a lag of about four quarters. Moreover, while the negative impact occurs between four and 16 quarters in the case of the output gap, it has more persistent effects in the case of the inflation rate. 
Figure 1: Impulse-response functions to a positive interest rate shock: BSVAR model and securities' brokers and dealers.

OG

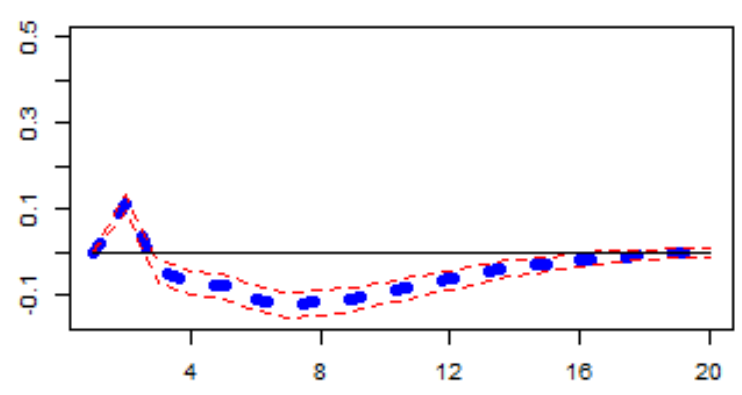

FFRATE

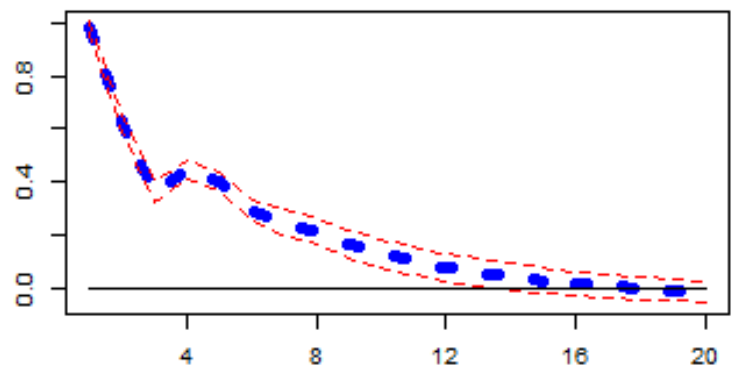

INFL

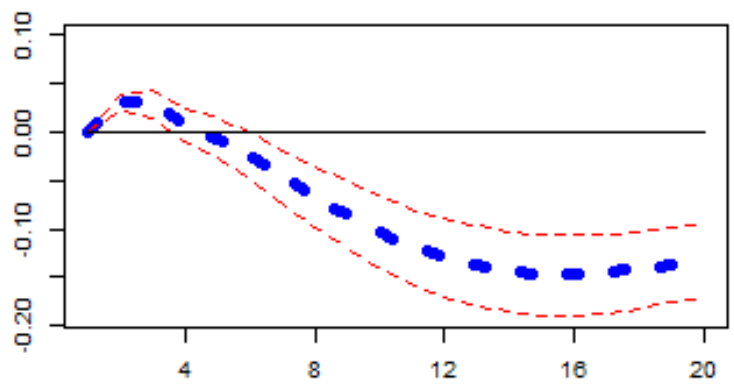

SBRDL

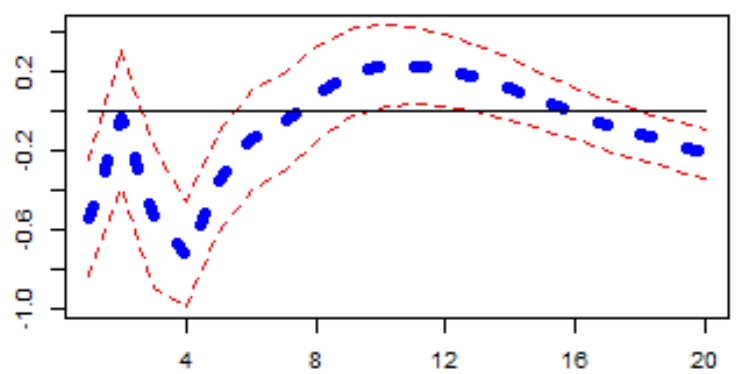

Notes: Blue dashed line - median response; red dashed lines - 68\% posterior confidence intervals computed by a Monte-Carlo MarkovChain (MCMC) algorithm based on 50000 draws. 
Figure 2: Impulse-response functions to a positive interest rate shock: BSVAR model and shadow banks.

OG

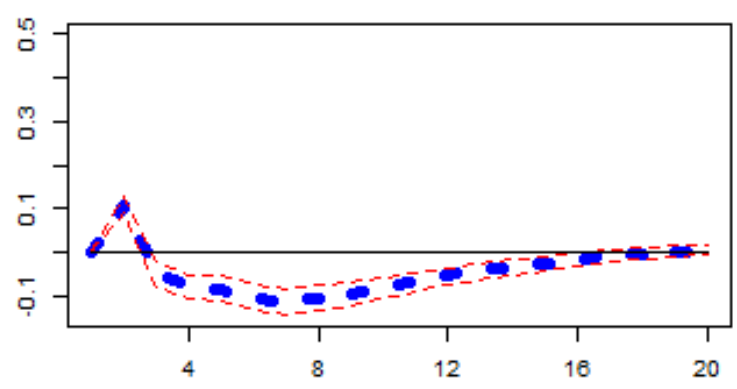

FFRATE

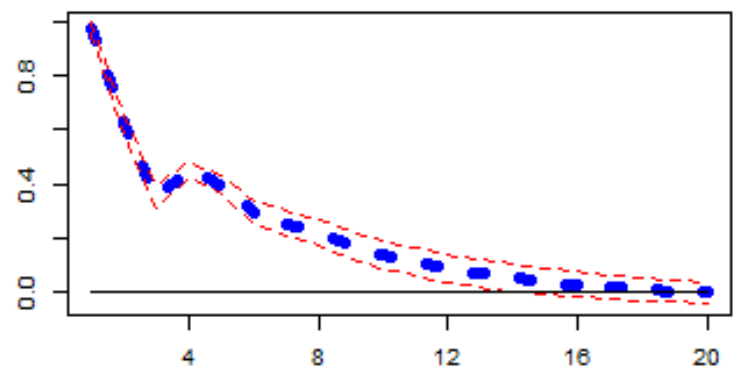

INFL

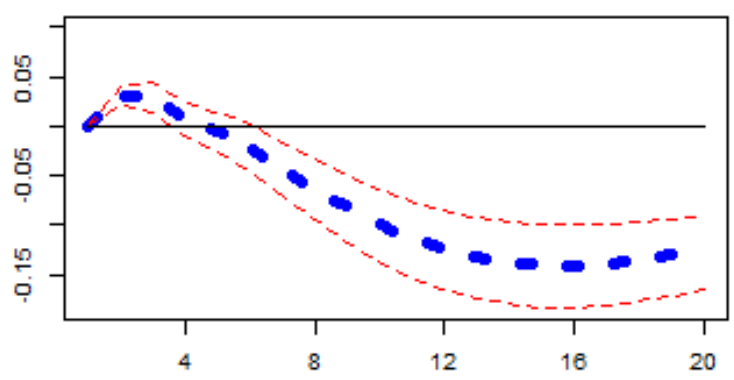

SHADBNK

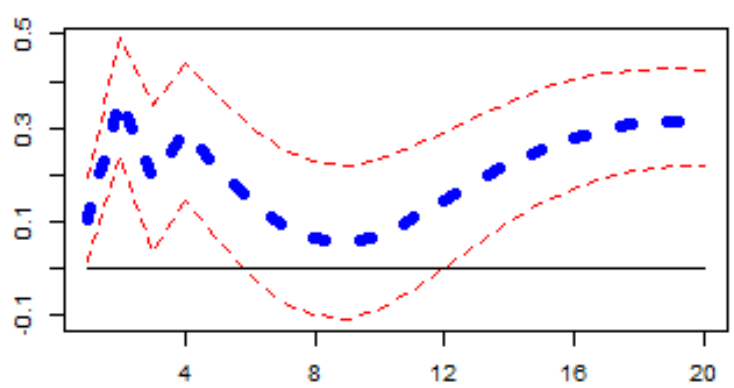

Notes: Blue dashed line - median response; red dashed lines - 68\% posterior confidence intervals computed by a Monte-Carlo MarkovChain (MCMC) algorithm based on 50000 draws.

\subsubsection{MSVAR model}

We now assess the relationship between U.S. monetary policy and the balance sheet of nonbanking financial sectors within a two-regime Markov-Switching framework. In order to distinguish between the role played by the different non-banking entities, we estimate two MS-VAR models where the growth rates of financial assets of securities' brokers and dealers (SBRDL) and shadow banks $(S H A D B N K)$ are alternatively treated as endogenous variables.

Each equation from the two MS-VAR models that describe the federal funds rate can be interpreted as an augmented U.S. monetary policy reaction which explains whether and how the balance sheet dynamics of non-bank financial intermediaries imply a response by the central bank in order to ensure financial stability. 
The parameter estimates of such functions are reported in Table 6. Specifically, the first two columns provide evidence pertaining to the (nonlinear) influence of changes in assets held by brokers and dealers, while columns 3 and 4 refer to the impact of the (overall) shadow bank asset growth rate on the federal funds rate.

To better analyze the results from a policymaking angle and put them into an historical perspective, few charts are preliminarily presented. Figure 3 depicts the smoothed probabilities of regime 1 as (endogenously) identified from the two MS-VAR models. The red bars denote the U.S. recession periods as dated by the National Bureau of Economic Research (NBER).

Figure 3: Smoothed probabilities (Regime 1).

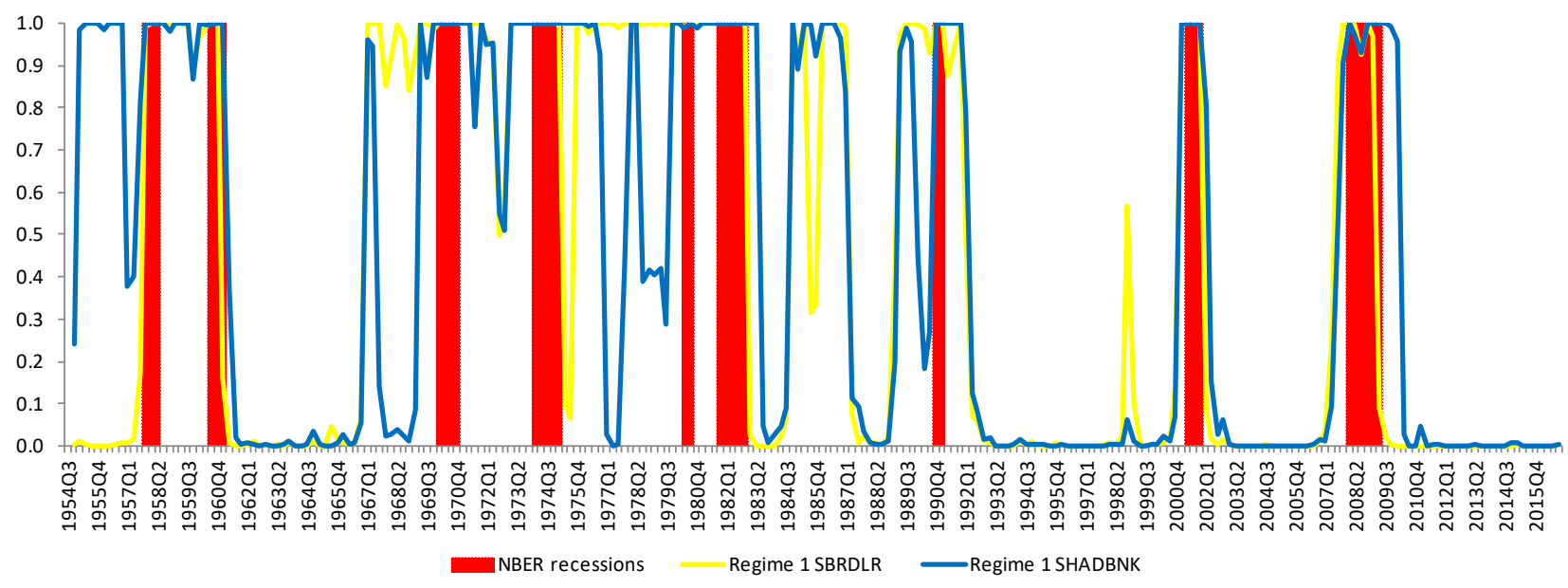

A simple visual inspection suggests that the dating of regime 1 is broadly the same for both model specifications. Interestingly, regime 1 encompasses the four major financial crises over the last 40 years in the US: (i) the commercial bank capital squeeze in 1973-1975; (ii) the savings and loan crisis (S\&L) in 1984-1991; (iii) the burst of the dotcom bubble in 2000-2001; and (iv) the financial crisis in 2007-2008. In addition, we note that, in most of the times, and, notably, since the eighties, regime 1 and U.S. recessionary episodes tend to overlap. 
The evolution of asset growth rates (blue and yellow lines) and the federal funds rate (black line) across the common regime 1 phases $^{13}$ (grey shaded area) and over the entire sample of analysis is depicted in Figure 4. As expected, the asset growth of securities' brokers and dealers and shadow banks share the same pattern, with the former being more volatile than the latter. At a first glance, both series tend to decline during regime 1 and to moderately increase during regime 2 and notably in the run-up to financial crises. With regard to the dynamics of federal funds rate, if we exclude the period of the seventies, we observe that the most significant cuts in the federal funds rate occurred during regime 1, while monetary tightening tends to occur during regime 2 .

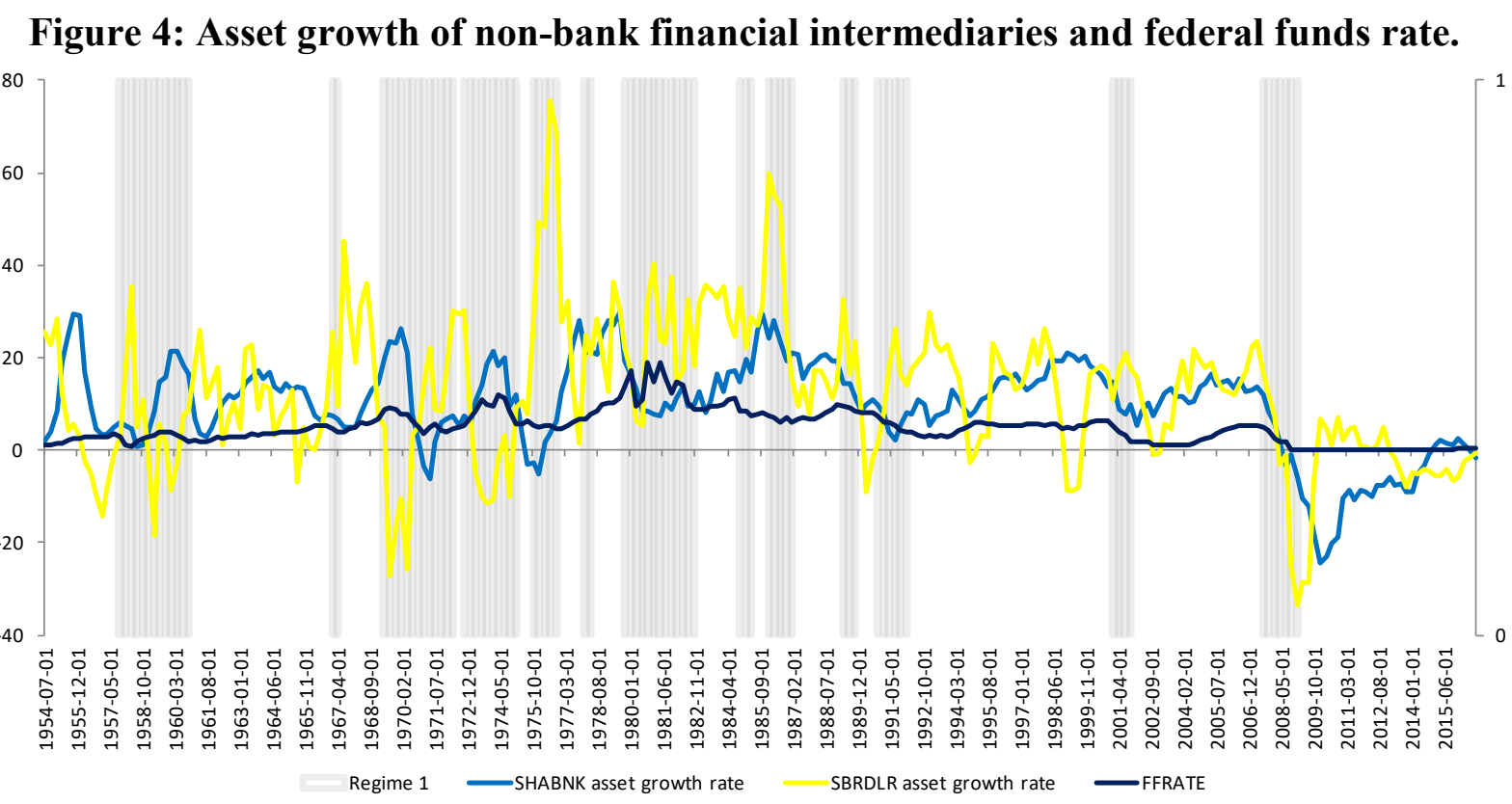

Putting such visual evidence together with the estimates reported in Table 6, we note that the U.S. monetary policy behaves in a counter-cyclical way. In fact, the signs and the statistical significance of the coefficients associated with inflation and output gap suggest that, during both regimes, the Federal Reserve takes action by dampening inflationary pressures or boosting growth when the economy is lagging. Moreover, the estimates across regimes indicate that the federal funds

\footnotetext{
${ }^{13}$ These refer to the overlapping periods of regime 1 as identified from the two MS-VAR models where the growth rates of financial assets of securities' brokers and dealers (SBRDL) and shadow banks (SHADBNK) are, alternatively, treated as endogenous variables.
} 
rate adjusts to fluctuations in the asset growth rate of non-bank financial intermediaries in a nonlinear fashion. More specifically, while there is no statistical evidence of a causal relationship going from asset growth to interest rates during regime 2 (i.e. U.S. monetary policy is neutral vis-à-vis changes in asset values), in regime 1, the (sharp) collapse of asset growth rates affecting brokers and dealers is associated with a significant decline in the federal funds rate.

Even though, our estimates indicate that part of such monetary policy corrections are consistent with the policy strategy that prescribes an accommodative stance during bad times (i.e. negative output gap and low inflation), the statistical significance of the asset growth variable $(S B R D L)$ and the positive sign associated with its coefficient also suggests that the Fed further focuses on the dynamics of these financial intermediaries as they gauge financial risks. Therefore, in line with the so-called "leaning against the wind" policy view, financial stability objectives appear to lead to the adoption of a more aggressive posture by the central bank: in response to negative shocks, as reflected in the sharp deterioration of brokers and dealers' balance sheets, interest rate cuts are deeper than otherwise.

Table 6: Monetary policy and shadow banking - MSVAR model.

\begin{tabular}{|c|c|c|c|c|}
\hline & \multicolumn{2}{|c|}{ Brokers and dealers } & \multicolumn{2}{|c|}{ Shadow banking } \\
\hline & $(1)$ & $(2)$ & (3) & $(4)$ \\
\hline & Regime 1 & Regime 2 & Regime 1 & Regime 2 \\
\hline \multirow[t]{2}{*}{ L.FFRRATE } & $0.7575^{\star * *}$ & $1.0089^{* * *}$ & $0.8070^{* * *}$ & $0.9905^{* * *}$ \\
\hline & (15.2500) & $(81.2874)$ & $(16.4711)$ & $(52.0061)$ \\
\hline \multirow[t]{2}{*}{ L.INFL } & $0.3033^{* * *}$ & $0.0491^{* *}$ & $0.2314^{* * *}$ & $0.1126^{* * *}$ \\
\hline & $(3.9404)$ & $(2.2559)$ & $(3.1046)$ & $(3.6444)$ \\
\hline \multirow[t]{2}{*}{ L.OG } & $0.3599 * * *$ & $0.0624^{* * *}$ & $0.2209^{* * *}$ & 0.0221 \\
\hline & $(4.9827)$ & $(3.2945)$ & $(3.0977)$ & $(0.6392)$ \\
\hline \multirow[t]{2}{*}{ L.SBRDL } & $0.0143^{* *}$ & 0.0030 & & \\
\hline & $(2.3400)$ & $(1.3761)$ & & \\
\hline \multirow[t]{2}{*}{ L.SHADBNK } & & & 0.0074 & 0.0052 \\
\hline & & & $(0.5122)$ & $(1.2387)$ \\
\hline \multirow[t]{2}{*}{ Constant } & -0.2108 & -0.0153 & -0.0461 & -0.1105 \\
\hline & $(-0.7592)$ & $(-0.3208)$ & $(-0.1769)$ & $(-1.6207)$ \\
\hline Log-Likelihood & -1431.5 & & -1193.5 & \\
\hline \multirow[t]{2}{*}{ Transition probability(i,j) } & 0.90 & 0.93 & 0.89 & 0.91 \\
\hline & 0.10 & 0.07 & 0.11 & 0.09 \\
\hline Ergodic probability & 0.41 & 0.59 & 0.44 & 0.56 \\
\hline
\end{tabular}


So far, we have discussed the rationale behind the monetary policy response to non-banking sector developments. However, given that all the variables entering our MS-VAR models are treated as endogenous, a reversal causal relationship running from changes in the federal funds rate to the balance sheet growth of financial intermediaries cannot be ruled out ex-ante. To shed some light on this potential linkage, we now focus on equations that explain the dynamics of the asset growth of securities' brokers and dealers and shadow banks.

The estimates are reported in Table 7, and we remark that the dating of the two regimes is the same as before. We find that a two-way (reversal causality) relationship exists, but it is mainly confined to a particular regime, i.e. regime 2 (when we account for securities' brokers and dealers) and, less significantly, to regime 1 (when we consider the shadow banking sector).

Table 7: Non-bank intermediaries' asset growth and monetary policy - MSVAR model.

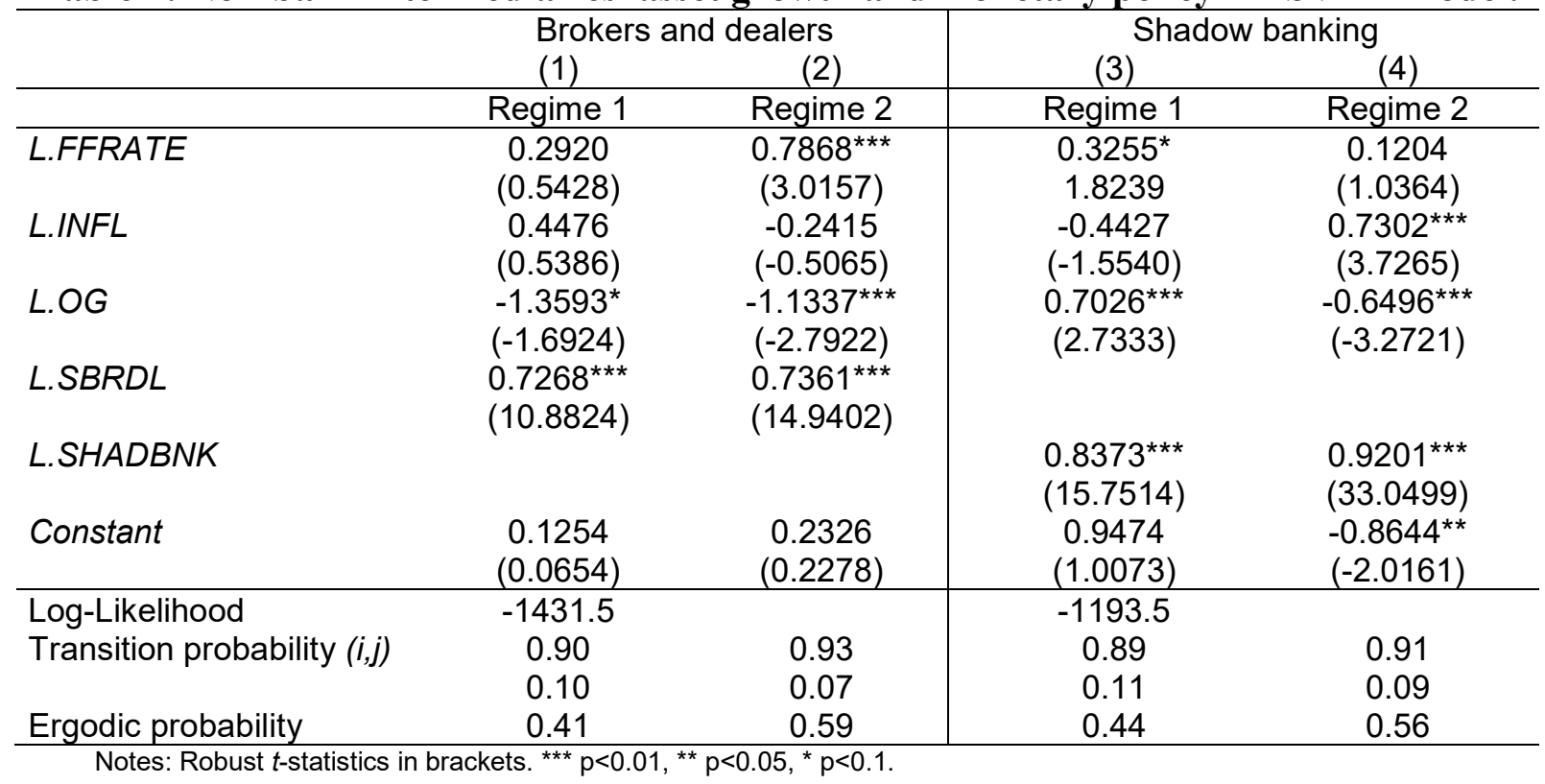

Moreover, we show that, in both cases, the interest rate policy has a positive impact on the dynamics of the asset growth. In fact, in regime 1, monetary contractions tend to expand the size of the shadow banking sector instead of reducing it. Analogously, in regime 2, monetary easing reduces the activity of securities' brokers and dealers. Thus, our empirical findings are in line with the work of den Haan and Sterk (2011). The authors show that, following a monetary policy 
contraction, non-bank mortgages increase, as opposed to standard bank mortgages which display a significant reduction. Nelson et al. (2018) also document this result as a "waterbed" effect, whereby commercial banks circumvent tighter funding liquidity constraints following a contractionary monetary policy shock by increasing their securitization activity. Consequently, there is a migration of lending beyond the regulatory perimeter of the shadow banking sector.

\section{Conclusion}

In this paper, we investigate the response of the central bank to the growth rate of the size of non-bank financial intermediaries. Using quarterly data for the U.S. over the period 1946:Q12016Q4 and various econometric frameworks, we find that an increase in the asset growth of the securities' brokers and dealers and the shadow banking sector is associated with a rise in the federal funds rate, as it is perceived as posing financial risks.

This result is not only observed by means of a single-equation model, but also confirmed by the estimation of multi-equation frameworks. Indeed, our Bayesian SVAR model shows that an unexpected monetary policy contraction leads to a fall on impact in both the asset growth rate of securities' brokers and dealers and the asset growth rate of the shadow banking sector, as a result of the deterioration in liquidity conditions. However, this response becomes positive six to eight quarters after the initial shock, thereby, suggesting that non-bank financial intermediaries overcome the challenge posed by the liquidity dry-up with an intensification of the activity of securitization.

Finally, the results of the MS-VAR model indicate that, in bad times, the Fed focuses on the dynamics of the size of the shadow banking sector, as it gauges financial risks. In line with the socalled "leaning against the wind" policy view, the mandate of financial stability increases the aggressiveness of monetary policy (Manna, 2018). Thus, in response to a sharp deterioration of the balance sheet of non-bank financial intermediaries, interest rate cuts are deeper than otherwise.

From a policy perspective, our study shows that the central bank responds to concerns about price stability and financial stability using a single policy instrument. More specifically, tracking 
the dynamics of the inflation rate and the output gap helps the monetary authority to anchor expectations about future inflation, as well as to smooth fluctuations in real economic activity. Additionally, accounting for the dynamics of the size of the balance sheet of non-bank financial intermediaries contributes to weather financial stability risks.

At the same time, our results corroborate the evidence in Nelson et al. (2018), namely, that contractionary monetary policy shocks are associated with a rise in the asset growth rate of securities' brokers and dealers and shadow banks and, more generally, securitisation activity - i.e. the so called "waterbed" effect. They are also close in spirit with the findings of Meeks et al. (2017), who show that economic vulnerabilities are amplified by risks stemming from the shadow banking system.

All in all, such findings raise questions about the effectiveness of the central bank's policy rate and the traditional transmission channel of monetary policy in the presence of non-bank financial intermediaries (Adrian and Shin, 2009). They also contribute to the debate concerning the optimal design of a combination of monetary and macro-prudential policies and financial sector regulation aimed at achieving medium-term price stability, promoting economic and safeguarding financial resilience.

\section{References}

Adrian, T., Etula, E., and H.S. Shin (2009). Risk appetite and exchange rates. Federal Reserve Bank of New York Staff Report no. 361.

Adrian, T., Erkko, E. Etula, and T. Muir (2014). Financial intermediaries and the cross-section of asset returns. Journal of Finance, 69(6), 2557-2596.

Adrian T., Moench, E., and H.S. Shin (2010). Financial intermediation, asset prices and macroeconomic dynamics. Federal Reserve Bank of New York Staff Report no. 422.

Adrian, T., and H.S. Shin (2008). Financial intermediary leverage and value at risk. Federal Reserve Bank of New York Staff Report no. 338. 
Adrian, T., and H.S. Shin (2009). Money, liquidity, and monetary policy. American Economic Review, 99(2), 600-605.

Adrian, T., and H.S. Shin (2010a). Financial intermediaries and monetary economics. Handbook of Monetary Economics, 3, Chap. 12, 601-650.

Adrian, T., and H.S. Shin (2010b). Liquidity and leverage. Journal of Financial Intermediation, $19(3), 418-437$.

Agnello, L., Castro, V., and R.M. Sousa (2012). How does fiscal policy react to wealth composition and asset prices? Journal of Macroeconomics, 34(3), 874-890.

Agnello, L., Castro, V., and R.M. Sousa (2013). What determines the duration of a fiscal consolidation program? Journal of International Money and Finance, 37, 113-134.

Agnello, L., Castro, V., and R.M. Sousa (2015). Booms, busts and normal times in the housing market. Journal of Business \& Economic Statistics, 33(1), 25-45.

Agnello, L., Castro, V., and R.M. Sousa (2018a). The legacy and the tyranny of time: Exit and reentry of sovereigns to international capital markets. Journal of Money, Credit and Banking, 50(8), 1969-1994.

Agnello, L., Castro, V., and R.M. Sousa (2018b). Financial markets' shutdown and re-access. Economic Inquiry, 56(1), 562-571.

Allen, W.A. (2015). Asset choice in British central banking history, the myth of the safe asset, and bank regulation. Journal of Banking and Financial Economics, 2(4), 18-31.

Angeloni, I., Faia, E., and M. Lo Duca (2015). Monetary policy and risk taking. Journal of Economic Dynamics \& Control, 52, 285-307.

Aoki, K., Proudman, J., and G. Vlieghe, G. (2004). House prices, consumption, and monetary policy: a financial accelerator approach. Journal of Financial Intermediation, 13, 414-435.

Arestis, P., Chortareas, G., Magkonis, G., and D. Moschos (2014). Inflation targeting and inflation convergence: International evidence. Journal of International Financial Markets, Institutions and Money, 31(C), 285-295. 
Barwell, R. (2018). Macroprudential policy. In: Mizen, P., Rubio, M., and P. Turner (eds.). Macroprudential policy and practice. Chapter 12, 275-302. Cambridge University Press: Cambridge, UK.

Bernanke, B., and M. Gertler (2001). Should central banks respond to movements in asset prices? American Economic Review, 91, 253-257.

Bernanke, B., and K. Kuttner (2005). What explains the stock market's reaction to Federal Reserve policy? Journal of Finance, 60(3), 1221-1257.

Berrospide, J.M., and R.M. Edge (2010). The effects of bank capital on lending: What do we know, and what does it mean? International Journal of Central Banking, 6, 5-54.

BIS (2014). 84th Annual Report, Bank for International Settlements: Basel, Switzerland.

BIS (2015). 85th Annual Report. Bank for International Settlements: Basel, Switzerland.

BIS (2016). 86th Annual Report, Bank for International Settlements: Basel, Switzerland

Bjornland, H., Jacobsen, C., and D. Henning (2010). The role of house prices in the monetary policy transmission mechanism in small open economies. Journal of Financial Stability, 6, 218229.

Borio, C. (2018). Macroprudential frameworks: experience, prospects and a way forward. Speech on the occasion of the Annual General Meeting of the BIS, Basel, Switzerland, 24 June.

Borio, C., and P. Lowe (2002). Asset prices, financial and monetary stability: exploring the nexus. BIS Working Paper no. 114.

Borio, C., and H. Zhu (2008). Capital regulation, risk-taking and monetary policy: a missing link in the transmission mechanism? BIS Working Paper no. 268.

Carey, M., Post, M., and S.A. Sharpe (1998). Does corporate lending by banks and finance companies differ? Evidence on specialization in private debt contracting. Journal of Finance, 53(3), 845-878.

Castro, V. (2011). Can central banks' monetary policy be described by a linear (augmented) Taylor rule or by a nonlinear rule? Journal of Financial Stability, 7(4), 228-246. 
Castro, V., and R.M. Sousa (2012). How do central banks react to wealth composition and asset prices? Economic Modelling, 29, 641-653.

Chadha, J.S. (2018). The new art of central banking. In: Mizen, P., Rubio, M., and P. Turner (eds.). Macroprudential policy and practice. Chapter 4, 87-107. Cambridge University Press: Cambridge, UK.

Chadha, J., Sarno, L., and G. Valente (2004). Monetary policy rules, asset prices, and exchange rates. IMF Staff Papers, 51, 529-552.

Chortareas, G. (2013). Fiscal policy rules in monetary unions. Journal of Post Keynesian Economics, 36(1), 85-104.

Christiano, L.J., Eichenbaum, M., and C.L. Evans (2005). Nominal rigidities and the dynamic effects of a shock to monetary policy. Journal of Political Economy, 113(1), 1-45.

Claessens, S. (2016). Regulation and structural change in financial systems. ECB Forum on Central Banking, June.

Clarida, R., Gali, J. and M. Gertler (1998). Monetary policy rules in practice. Some international evidence. European Economic Review, 42, 1033-1067.

Davig, T. (2004). Regime-switching debt and taxation. Journal of Monetary Economics, 51, 837859.

den Haan, W. J., and V. Sterk (2011). The myth of financial innovation and the Great Moderation. Economic Journal, 121(553), 707-739.

Duffie, D. (2010). The failure mechanics of dealer banks. Journal of Economic Perspectives, 24(1), $51-72$.

Dufrénot, G., Jawadi, F., and A. Khayat (2018). A model of fiscal dominance under the "Reinhart Conjecture". Journal of Economic Dynamics and Control, 93, 332-345.

Field, A.J. (2015). The Taylor rule in the 1920s.Santa Clara University, Department of Economics, manuscript. 
Filardo, A., and P. Rungcharoenkitkul (2016). A quantitative case for leaning against the wind. BIS Working Paper no. 594.

Flannery, M.J. 1981. Market interest rates and commercial bank profitability: An empirical investigation. Journal of Finance, 36(5), 1085-1101.

Georgiadis, G. (2014). Towards an explanation of cross-country asymmetries in monetary transmission. Journal of Macroeconomics, 39(A), 66-84.

Granville, B., and S.K. Mallick (2009). Monetary and financial stability in the euro area: Procyclicality versus Trade-off. Journal of International Financial Markets, Institutions \& Money, 19(4), 662-674.

Hamilton, J.D. (1988). Rational-expectations econometric analysis of changes in regime: an investigation of the term structure of interest rates. Journal of Economic Dynamics and Control, $12,385-423$.

Hamilton, J.D. (1990). Analysis of time series subject to changes in regime. Journal of Econometrics, 45, 39-70.

Hamilton, J.D. (2005). What's real about the business cycle? National Bureau of Economic Analysis, NBER Working Paper no. 11161.

Hammoudeh, S., Nguyen, D.K., and R.M. Sousa (2015). US monetary policy and commodity sector prices. Journal of International Money and Finance, 57, 61-85.

Iacoviello, M. (2005). House prices, borrowing constraints, and monetary policy in the business cycle. American Economic Review, 95, 739-764.

Iacoviello, M. and R. Minetti (2008). The credit channel of monetary policy: evidence from the housing market. Journal of Macroeconomics, 30, 69-96.

Iacoviello, M., and S. Neri (2010). Housing market spillovers: evidence from an estimated DSGE model. American Economic Journal: Macroeconomics, 2(2), 125-164.

Igan, D., A. Kabundi, F.N. Simone, and N. Tamirisa (2013). Monetary policy and balance sheets. IMF Working Paper no. 158. 
IMF (2016). Fostering stability in a low-growth, low-rate era. Global Financial Stability Report, October, chapter two.

Ingves, S. (2017). Monetary policy challenges - weighing today against tomorrow. Speech at the Swedish Economics Association, Stockholm, Sweden, 17 May.

Jalles, J.T. (2015a). Panel causality and cointegration between productivity and unemployment. Applied Economics Quarterly, 61(2), 141-153.

Jalles, J.T. (2015b). Is there a long-run relationship between unemployment and productivity? Comparative Economic Research, 18(2), 57-75.

Jalles, J.T. (2015c). How quickly is news incorporated in fiscal forecasts? Economics Bulletin, 35(4), 2802-2812.

Jalles, J.T. (2016). A new theory of innovation and growth: the role of banking intermediation and corruption. Studies in Economics and Finance, 33(4), 488-500.

Jalles, J.T. (2017a). Forecasting performance of private sector's unemployment forecasts in advanced economies. International Review of Applied Economics, 31(6), 707-733.

Jalles, J.T. (2017b). On the rationality and efficiency of inflation forecasts: Evidence from advanced and emerging market economies. Research in International Business and Finance, 40, 175-189.

Jawadi, F., Mallick, S.K., and R.M. Sousa (2014). Fiscal policy in the BRICs. Studies in Nonlinear Dynamics and Econometrics, 18(2), 201-215.

Jawadi, F., Namouri, H., and Z. Ftiti (2018). An analysis of the effect of investor sentiment in a heterogeneous switching transition model for G7 stock markets. Journal of Economic Dynamics and Control, 91, 469-484.

Jawadi, F., Sousa, R.M., and R. Traverso (2017). On the macroeconomic and the wealth effects of unconventional monetary policy. Macroeconomic Dynamics, 21(5), 1189-1204.

Jeanne, O., and P. Masson (2000). Currency crises, sunspots, and Markov-switching regimes. Journal of International Economics, 50, 327-350.

Kenç, T. (2016). Macroprudential regulation: history, theory and policy. BIS Papers, no. 86, 1-15. 
Krolzig, H.M. (1997). International business cycles: Regime shifts in the stochastic process of economic growth. University of Oxford, Applied Economics Discussion Paper No. 194.

Leeper, E.M., and T. Zha (2003). Modest policy interventions. Journal of Monetary Economics, 50(8), 1673-1700.

Loutskina, E. (2011). The role of securitization in bank liquidity and funding management. Journal of Financial Economics, 100(3), 663-684.

Łupiński, M. (2018). Macroprudential tools of systemic risk analysis. In: Mizen, P., Rubio, M., and P. Turner (eds.). Macroprudential policy and practice. Chapter 10, 225-247. Cambridge University Press: Cambridge, UK.

Mallick, S.K., Mohanty, M.S., and F. Zampolli (2017). Market volatility, monetary policy and the term premium. BIS Working Paper, no. 606.

Mallick, S.K., and M. Mohsin (2016). Macroeconomic effects of inflationary shocks with durable and non-durable consumption. Open Economies Review, 27(5), 895-921.

Mallick, S.K., and R.M. Sousa (2012). Real effects of monetary policy in large emerging economies. Macroeconomic Dynamics, 16(S2), 190-212.

Mallick, S.K., and R.M. Sousa (2013). The real effects of financial stress in the Eurozone. International Review of Financial Analysis, 30, 1-17.

Manna, I. (2018). Can we still lean against the wind? Asset price volatility and optimal policy mix in overlapping generations model. Open Economies Review, 29(2), 223-259.

Meeks, R., Nelson, B., and P. Alessandri (2017). Shadow banks and macroeconomic instability. Journal of Money, Credit and Banking, 49(7), 1483-1516.

Nelson, B., Pinter, G., and K. Theodoris (2018). Do contractionary monetary policy shocks expand shadow banking? Journal of Applied Econometrics, 33(2), 198-211.

Orphanides, A. (2001). Monetary policy rules based on real-time data. American Economic Review, 91, 964-985. 
Orphanides, A. (2003). Monetary policy evaluation with noisy information. Journal of Monetary Economics, 50, 605-631.

Papademos, L., 2009. Financial stability and macro-prudential supervision: objectives, instruments and the role of the ECB. Speech at the conference "The ECB and Its Watchers XI", Frankfurt, Germany, 4 September.

Pozsar, Z., Adrian, T., Ashcraft, A., and H. Boesky (2010). Shadow banking. Federal Reserve Bank of New York, Staff Report no. 458.

Primiceri, G.E. (2005). Time varying structural vector autoregressions and monetary policy. Review of Economic Studies, 72(3), 821-852.

Rafiq, M.S., and S.K. Mallick (2008). The effect of monetary policy on output in EMU3: A sign restriction approach. Journal of Macroeconomics, 30, 1756-1791.

Reinhart, D., and R. Sowerbutts (2018). Macroprudential policy in a globalised world. In: Mizen, P., Rubio, M., and P. Turner (eds.). Macroprudential policy and practice. Chapter 8, 178-204. Cambridge University Press: Cambridge, UK.

Rigobon, R., and B. Sack (2004). The impact of monetary policy on asset prices. Journal of Monetary Economics, 51, 1553-1575.

Rotemberg, J. (2014). The Federal Reserve's abandonment of its 1923 principles. NBER Working Paper no. 20507.

Rudebusch, G.D. (2002). Term structure evidence on interest-rate smoothing and monetary policy inertia. Journal of Monetary Economics, 49, 116-187.

Serletis, A., and K. Istiak (2018). Broker-dealer leverage and the stock market. Open Economies Review, 29(2), 215-222.

Sims, C.A., and T. Zha (1999). Error bands for impulse-responses. Econometrica, 67(5), 11131155.

Sims, C.A., and T. Zha (2006a). Were there regime switches in U.S. monetary policy? American Economic Review, 96(1), 54-81. 
Sims, C.A., and T. Zha (2006b). Does monetary policy generate recessions? Macroeconomic Dynamics, 10(2), 231-272.

Sousa, R.M. (2010). Housing wealth, financial wealth, money demand and policy rule: evidence from the euro area. North American Journal of Economics and Finance, 21, 88-105.

Stock, J., and M. Watson (1993). A simple estimator of cointegrating vectors in higher order integrated systems. Econometrica, 61(4), 783-820.

Svensson, L.E.O. (2017). Leaning against the wind: The role of different assumptions about the costs. NBER Working Paper no. 23745.

Taylor, J.B. (1993). Discretion versus policy rules in practice. Carnegie-Rochester Conference Series on Public Policy, 39, 195-214.

Taylor, J.B. (2009). The financial crisis and the policy responses: An empirical analysis of what went wrong. National Bureau of Economic Research, NBER Working Paper no. 14631.

Turner, P. (2017). Did central banks cause the last financial crisis? Will they cause the next? LSE Financial Markets Group (FMG) Paper Series, Special Paper no. 249.

Turner, P. (2018). The macroeconomics of macroprudential policies. In: Mizen, P., Rubio, M., and P. Turner (eds.). Macroprudential policy and practice. Chapter 1, 19-45. Cambridge University Press: Cambridge, UK.

van den Heuvel, S.J. (2007). Does bank capital matter for the transmission of monetary policy? Economic Policy Review, 8(1), 161-172.

White, W.R. (2001). Changing views on how best to conduct monetary policy: the last fifty years. Speech at the Reserve Bank of India, Mumbai, India, 14 December.

Wongswan, J. (2009). The response of global equity indexes to US monetary policy announcements. Journal of International Money and Finance, 28, 344-365.

Woodford, M. (2003). Interest and prices: foundations of a theory of monetary policy. Princeton University Press: Princeton, USA. 